\title{
The Decade 1989-1998 in Spanish Psychology: An Analysis of Research in Basic Psychological Processes, History of Psychology, and Other Related Topics
}

\author{
José Manuel Igoa \\ Autonomous University of Madrid
}

\begin{abstract}
This article presents a review of research published by Spanish Faculty from the area of basic psychology in the decade 1989-1998. It provides information about research on basic psychological processes commonly studied under the labels of experimental and cognitive psychology, plus a number of topics from other research areas, including some applied psychology issues. The review analyzes the work of 241 faculty members from 27 different Spanish universities, as reflected in 1,882 published papers, book chapters, and books. The analyses carried out in this report include a description of the main research trends found in each area, with some representative references of the published materials, and statistics showing the distribution of this research work in various relevant publications (both Spanish and foreign), with figures that reveal the impact of this work both at a national and international scale.
\end{abstract}

\begin{abstract}
Este articulo ofrece una revisión de la investigación publicada por profesores del área de psicología básica de las universidades españolas durante la década 1989-1998. La revisión abarca la investigación sobre procesos psicológicos básicos, comúnmente encuadrados bajo el título de psicología experimental y cognitiva, asi como sobre otros temas pertenecientes a diversas áreas de la psicología, incluyendo también cuestiones de psicología aplicada. Se analiza el trabajo de 241 investigadores pertenecientes a 27 universidades españolas, según se réleja en 1.882 artículos, capitulos de libros y libros. Los análișis llevados a cabo en este informe contienen una descripción de las principales líneas de investigación de cada área, que se acompaña de referencias de trabajos representativos publicados, y algunos datos estadísticos relativos a la distribución de los trabajos de investigación en diversos tipos de publicaciones (españolas y extranjeras) y a los indices de impacto de dichos trabajos a escala nacional e internacional.
\end{abstract}

Acknowledgements. I wish to thank all those faculty members of basic psychology who kindly responded to my request for information about their published work. I also wish to express my gratitude to Miguel Angel García-Pérez and Jesús Sanz for supplying useful information about Cognitive Psychology research by authors from the areas of Methodology and Health and Clinical Psychology, respectively, and especially to Juan Fernández for his patience and support throughout the long period of preparation of this article.

Correspondence concerning this article should be addressed to the author, Departamento de Psicología Básica, Facultad de Psicología, Universidad Autónoma de Madrid. Campus de Cantoblanco, 28049 Madrid, Spain (E-mail: josemanuel.igoa@uam.es). 
This article offers a broad survey of the research carried out during the decade 1989-1998 in the areas of experimental and cognitive psychology, plus other related research topics, as reflected in relevant published work by faculty members (i.e., tenured professors) pertaining to the area known as psicología básica (literally, basic psychology) in Spanish universities. As we shall see, the research reviewed in this paper covers an extremely wide range of topics, extending far beyond the fundamental ones usually addressed in experimental and cognitive psychology, namely higher psychological processes such as attention, perception, learning, memory, language, and reasoning. This is a consequence of the division of labor in the comprehensive review of research fields in Spanish psychology covered in this issue, which mirrors the organization of psychology areas in Spanish university departments. In this regard, basic psychology is one of the most diversified fields in terms of research interests among Psychology departments and units in Spain.

Another fact that also accounts for this dispersion of research interests is the high number of faculty members in the departments of Basic Psychology across Spanish universities (241 ${ }^{\mathrm{I}}$ professors as of December 1998), and the individualistic trend usually found in research practices in the social sciences in Spain. Given the huge amount and the wide breadth of information that this article reviews, $l$ will begin by giving an overview of the issues addressed in it.

The aim of the first section is to clarify the notion of basic psychology and to relate it to major fields of research in the discipline. At the same time, this section includes a list of the main research topics to be covered in later sections, classified under some major headings used in psychology. The second section provides a brief account of the procedures that were followed in order to collect the information on which this review is based. The third section presents a general overview of the distribution among various psychology topics of the research work done by faculty members of the departments of Basic Psychology throughout Spanish universities, providing general figures that may give some hint about the relative weight given to these topics by Spanish researchers during the 1989-1998 decade. In addition, it analyzes the research trends of Spanish Basic Psychology departments by surveying the impact of this research on international and Spanish journals, as measured by their contribution of articles to these journals. Section four addresses the main body of research concerning the major topics within the fields of experimental and cognitive psychology. The main trends and topics of research are outlined, and some of the most prominent contributions of Spanish researchers highlighted. Section five reviews other research topics, mainly in applied fields of psychology, which are also the focus of interest of researchers from Basic Psychology departments in Spain. The article ends with some final comments on the state of the art of experimental and cognitive psychology in Spain, as may be inferred from the information discussed in this paper.

\section{Basic Psychology: A Mixed Bag}

The term basic psychology, as it is used to describe a set of related topics and fields of theoretical interest and empirical inquiry, was first proposed as a convenient label some twenty years ago, when Psychology departments and schools began to multiply and expand across Spanish universities. Psychology as a professional specialty and as a self-contained, full-fledged scientific discipline quickly became very popular among the Spanish youth as a professional target, and across the Spanish society at large. With this social demand at hand, it became necessary to develop different fields of specialization, one consequence being the creation of a number of new units and departments intended to perform research activities and undertake the professional training of students in various applied fields. Several theoretical disciplines devoted to studying psychological processes, such as attention, perception, learning, memory, language, problem solving, and reasoning, that were hitherto lumped together under the heading of general psychology, plus other disciplines focusing on methodological and historical aspects of the new emerging science, were gathered under the basic psychology label. This led to the creation of a new, rather heterogeneous set of subjects and disciplines that was to form the core of new administrative divisions, and later on, departments, bearing the same label in the schools and faculties of Psychology that were being founded across the country.

Mainly for historical reasons, and fostered by the new laws of Higher Education voted by the Spanish Congress at the beginning of the eighties (the so-called Ley de Reforma Universitaria or LRU [Law of University Reform]), which bestowed a great deal of autonomy on the universities, Basic Psychology departments began to follow different paths at different universities, on the basis of the each university's idiosyncrasy. The only constraint was to include a number of core disciplines or subjects in their programs and syllabuses. Research interests and trends, however, remained disunited; some departments of Basic Psychology became, or continued to be, interested in experimental research on psychological processes, whereas others fell back on applied psychology in various fields (e.g.,. health psychology, applied social psychology, developmental and educational psychology, etc.). A very common picture today, which will become evident in later sections of this paper,

\footnotetext{
1 One professor that was missing in the official list comprising 240 faculty members (see Fernández, this issue) has been added to the count for this review.
} 
is that two or more different avenues of research are followed by different faculty members within a single Basic Psychology department, each one supported quite often by a scant number of professors. Accordingly, this multiplication and diversification of research topics has become a hindrance for the development of research teams, let alone for interdisciplinary research, which continues to be exceptional nowadays in this field of psychology in our country.

To what extent is basic psychology, in the sense described above, basic? The adjective basic is used here not to ascribe an introductory or elementary character to the disciplines and topics included in this field of psychology, but rather to define the field as more fundamental (and perhaps more general) than other areas of psychology. In this regard, basic psychology covers a wider range of topics of study than other areas, as it encompasses all psychological processes, mechanisms, and resources that are involved in human (and occasionally, animal) behavior as they have been traditionally studied in the past. The core topics are classified as a set of horizontally construed faculties in the Fodorian sense of the term (Fodor, 1983) -i.e., attention, perception, learning, memory, language and thought-plus other traditional psychological themes such as motivation and emotion, and one more topic, which deals with the study of psychology as a scientific discipline from a historical perspective. Although the dominant methodological perspective in Spanish basic psychology is supposedly experimental and the major theoretical stance is seemingly cognitive $-\mathrm{a}$ trend that can be traced back to the early eighties, in the case of Spanish psychology - there is considerable leeway for other research methods and theoretical points of view. For instance, the trace of behaviorism is still clearly visible in some research areas.

On the other hand, if we draw a distinction between basic and applied research, the work reviewed in this article reveals that basic psychology in our country does not entirely honor its name as far as research trends are concerned. Notwithstanding the fact that the boundary between basic and applied research is fuzzy and to some extent controversial, a survey of the 1,882 research papers, book chapters, and books that constitute the database used in this article renders the following figures: 1,290 works were devoted to basic research in psychology (68.5\%), whereas the remaining 592 works fell under applied psychology topics (31.5\%).

Tuming to the main fields of research represented in this review, the work covered in this article has been classified according to the list shown in Table 1, on the basis of a loose dichotomy between basic psychology topics and topics from other research areas. Basic psychology themes include: (1) main psychological processes such as attention, learning, memory, perception, language, and thought; (2) other psychological phenomena, such as emotion and motivation, which strictly speaking fall outside the realm of psychological processes; (3) history of psychology; and (4) miscellaneous topics covered by basic psychology researchers that do not fit within any of the previous categories.
Table 1

Main Topics Covered in the Present Survey of Basic Psychology Research

BASIC PSYCHOLOGY

Attention
Emotion
History of psychology
Learning
Memory
Motivation
Perception
Psycholinguistics
Thinking and reasoning
Miscellaneous topics; cognition and intelligence; cognitive
impairments; consciousness; creativity; culture and psychology;
theoretical psychology.

\section{OTHER ISSUES}

Animal psychology

Developmental psychology

Educational psychology

Health and clinical psychology

Methodology

Miscellaneous topics in applied psychology: aeronautics; judicial psychology; psychology of art.

Neuropsychology

Personality and individual differences

Psychophysiology

Psychological assessment

Psychology of gender

Psychology of road safety and driving behavior

Social psychology

Sport psychology

As we shall see in Section 3, the distribution of research trends among the previously listed topics and the amount of research work in each one of them are not in the least uniform. By way of an example, the subfield of history of psychology by itself contributes nearly $40 \%$ of the research papers within the basic psychology category $25 \%$ in the overall count). At the other end, research on motivation covers only $1 \%$ of the published materials in the basic psychology group $(0.6 \%$ overall).

Another issue that deserves some comment concerns the appropriateness of the labels experimental and cognitive for the research work reflected in this paper, and for the kind of research that Spanish "basic psychologists" carry out. If we make a rough estimation of the percentage of published research items in our database (articles, book chapters, and books) that can be characterized by either of these two labels, we find that no more than $40 \%$ of them could be properly considered experimental, and perhaps 
slightly over $30 \%$ could be labeled cognitive. The reason for this probably lies in the relatively high proportion of work devoted to historical and theoretical issues, on the one hand, and to the fairly strong interest in applied research, on the other.

\section{Data Collection and Classification}

The procedures followed to collect the information on which the reports of this issue are based have been described in detail in the introductory paper by Fernández (this issue). However, there are some peculiarities about the collection of data for this article that deserve closer inspection. As it has been reported, the bulk of information concerning published work by faculty members of Spanish Psychology departments comes from a number of international and national sources that were searched to supply a list of published papers signed by their authors' surnames (see Fernández, this issue, for details). Given the variety of ways in which these names appeared in the papers, and as quite often the identity of authors could only be established and discriminated by the authors' first names -and these were quite often only available as initials- this search procedure produced both many false positive cases and quite a number of misses.

In order to properly clean up and update the database, all 240 faculty members of the departments and areas of basic psychology around the country (belonging to 27 different universities) were contacted by letter or e-mail (the author of this paper was obviously excluded). They were requested to provide a list of references of their publications between 1989 and 1998 that complied with the requirements described in Fernández's article (this issue). Whenever available, they were given the original list of publications appearing in our files. Only 99 out of 240 potential authors replied (41\%) -, and very few of them complied exactly with our request. Instead, most correspondents provided a full list of their publications from that period, of whichever nature, or even beyond the requested period. The new list was then closely examined to remove inappropriate items (i.e., textbooks, popular science articles and books, reviews, abstracts published in conference proceedings, and the like), and especially to check for repeated entries with several co-authors -thus appearing once under each co-author's name in our list. This rendered the 1,882 items previously mentioned: 1,493 (79.33\%) journal articles, and 389 (20.66\%) books ${ }^{2}$ and book chapters. No attempt was made to assess the quality of the papers or the relevance of the contributions therein, and no attention was paid to the publication (book or journal) in which they appeared for the purpose of selection. The only criterion used for that purpose was that the contributions eligible for inclusion in our database should result from their authors' original research work. For that matter, this criterion was liberally applied.

With this final collection of references, several computations were performed in order to yield the descriptive analyses shown in subsequent sections of this paper. However, given the partial response to our request for information from the faculty members, and the unavoidably limited scope of the present report, the information provided in this paper should not be viewed as a thorough assessment of the state of the art of research in basic psychology, but rather as a modest and limited description of the major research trends in this area of acadernic psychology in Spain.

The analyses that will be shortly presented were based on the following counts and computations performed on the final list of references. First, every research publication was classified under one category of the list shown in Table 1. As will be seen in the next section, some categories (especially those from the basic psychology group) were broken down into subcategories, in order to compile a list of frequencies of publications by thematic criteria. This distributed arrangement of publications by fields will be discussed in Section 3 of this paper. Second, the 1,493 papers published in scientific journals -both Spanish and international-were classified according to the journals of publication, so as to provide a general picture of the kind of media in which Spanish authors publish their research work. The journals were, in turn, classified into four broad categories: two for general, experimental and cognitive psychology journals -one category with journals in Spanish and the other one with journals in a foreign language (English, in all but two cases)- and the other two for journals covering other areas, both within and beyond psychology -also separating Spanish and foreign journals. This classification of works by journals was carried out with the additional aim of assessing the local and international impact of the research work done by Spanish authors. Accordingly, the Basic Psychology departments and units of Spanish universities were ranked in terms of their relative impact in local and international journals, as measured by gross number of contributions to journals, as well as by the ratio of the number of published papers to the number of faculty members in each unit.

\footnotetext{
2 Forty-seven of these are books, either written, edited, or co-edited by Spanish authors. Twelve of these books were originally published in English. This is the distribution of these books by topics: artificial intelligence (1); attention (1); chronopsychology (1); creativity (1); information technology (1); educational psychology (6); general and cognitive psychology (3); history of psychology (10); learning (2); memory (3); motivation (1); neuropsychology (1); perception (3); psycholinguistics (5); psychology of gender (1); judicial psychology (2); reasoning (2); road safety and driving behavior (2); sport psychology (1).
} 
Once all the research contributions had been classified by thematic domains and by publications, a further count was carried out to unravel the most prominent research trends in Spanish basic psychology. As reported by Fernandez (this issue), a rather lax criterion was used to individualize these research trends, namely to locate at least five published research papers about a given topic signed by a core group of faculty members belonging to the area of Basic Psychology. Following the general dichotomy between basic psychology and Other Issues presented in Table 1, a brief descriptive analysis of these research trends will be provided in Sections 4 and 5 of this article, respectively. The categories employed in these analyses are of a medium-grain size, that is, they lie somewhere between a broad characterization of research domains -i.e., one using labels such as operant learning, historical analysis of psychological concepts, or deductive reasoning- and a detailed account of research topics - which could bear labels such as role of inflectional morphology in written word recognition. perception of safety and risk factors in driving behavior, or leaming of geographical maps in experts and novices, to give just a few examples. In view of the large amount of materials collected, an analysis of contents was virtually impossible to carry out. Therefore, the review presented below is limited to a brief statement of the main research trends and topics, together with a few representative references of each one of them, in English-written journals wherever possible.

\section{Research in Basic Psychology: Some General Facts and Figures}

The 1,882 research papers reviewed in this article are distributed among several major fields in psychology grouped under the general categories of basic psychology (1,219 papers; $64.8 \%$ ) and other issues ( 663 papers; $35.2 \%$ ). Tables 2 and 3 display lists of the fields used in this classification (some of them broken down into several different topics), with the number of articles classified under each field and its topics.

Some aspects of this classification should be clarified. First, as can be seen in the above figures, research trends on attention and perception are comparable, both in terms of the amount of published papers and in that both focus to a large extent on the visual modality.

Table 2

Distribution of Basic Psychology Papers by Fields and Topics: Frequency Data

\begin{tabular}{|c|c|c|c|}
\hline BASIC PSYCHOLOGY & 1,219 & Motivation & $12(1)$ \\
\hline Attention & $50(4.1)$ & Perception & $53(4.3)$ \\
\hline Applications & 4 & General issues & 6 \\
\hline Automaticity/control & 7 & Other modalities (haptic, auditory) & 7 \\
\hline Visual & 36 & Speech & 12 \\
\hline Other topics & 3 & Visual & 28 \\
\hline Emotion & $16(1.3)$ & Psycholinguistics & $234(19.2)$ \\
\hline History of psychology & $461(37.8)$ & Language acquisition & 20 \\
\hline Authors, classical and modern & 220 & Language production & 8 \\
\hline Conceptual issues & 52 & Lexical processing & 72 \\
\hline General issues & 12 & Normative studies & 8 \\
\hline Institutional and national issues & 46 & Syntactic parsing & 11 \\
\hline Topics of historical interest & 107 & Pragmatics and communication & 18 \\
\hline Schools & 24 & Reading & 32 \\
\hline Learning & $157(12.9)$ & Semantics and discourse & 58 \\
\hline Cognitive & 11 & Other issues & 7 \\
\hline General issues & 3 & Thinking and reasoning & $63(5.2)$ \\
\hline Classical conditioning & 62 & Causal reasoning & 5 \\
\hline Operant conditioning & 79 & Concepts & 11 \\
\hline Other issues & 2 & Deductive reasoning & 24 \\
\hline Memory & $100(8.2)$ & Problem solving & 4 \\
\hline Applications & 11 & Other issues & 19 \\
\hline Autobiographical & 3 & Miscellaneous topics & $73(6)$ \\
\hline General issues & 11 & Cognition and intelligence & 5 \\
\hline Basic processes & 14 & Cognitive impairments & 14 \\
\hline Mental imagery & 41 & Creativity & 7 \\
\hline Witness & 13 & Culture and psychology & 9 \\
\hline Other issues & 7 & Theoretical psychology & 38 \\
\hline
\end{tabular}

Note. The percentages of papers of each field of basic psychology are in brackets. 
Second, the topics listed under history of psychology that have roused more attention are the study of leading figures in contemporary psychology, mostly classical foreign authors such as Wilhelm Wundt, William James, John Watson, B.F. Skinner, Jean Piaget, or Lev Vygotsky, but also Spanish authors that have played a major role in the development of psychology and the behavioral sciences in Spain, such as Santiago Ramón y Cajal, Emilio Mira i López, or José Germain. The 220 papers published under this topic amount to almost $50 \%$ of the papers in the field. Most prominent also are studies on general topics in psychology from a historical perspective, such as the development of the psychology of motivation in Spain, the influence of psychoanalysis in Spanish psychology, or the historical evolution of psychological assessment procedures, to mention just a few examples (107 papers: 23\%). Similarly, a good number of works are devoted to discussing the historical development of schools of thought in psychology (e.g., behaviorism, the socio-historical school, constructivism, cognitivism), both at the international and national levels, as well as the development of Spanish institutions and joumals devoted to psychological issues. These two topics account for $15 \%$ of the publications in this field (with 70 published books and papers). Another visible trend in Spanish history of psychology is the historical review of relevant concepts in psychological science, such as natural selection, reinforcement, selective attention, activation, and many others, with 52 papers ( $11.3 \%$ ). Lastly, a very consolidated approach in the Spanish history of psychology, which I will explore in more detail in the next section of this paper, is the socalled bibliometric approach. This consists of an assessment of the impact of certain authors, institutions, or journals, either Spanish or foreign, by computing statistics on the number of items (articles or books) published about such authors and institutions, or by those journals.

As for the study of learning, the dominant trend is the experimental study of animal and human learning processes from an associationistic perspective, either operant or classical Pavlovian conditioning. In this regard, the study of learning from a cognitive framework is notoriously scarce.

An interesting, and perhaps striking, fact that can be drawn from the above classification is the comparatively low number of studies on memory. One possible reason stems from the fact that memory comprises a class of psychological processes that cuts across other psychological domains, such as learning, language, reasoning, or perception. Consequently, the study of memory as an enclosed domain on its own turns out to be exceptional. This is clearly illustrated by two facts: One is that as much as one fourth of the studies on memory deal with applied issues of various sorts, or refer to particular fields of memory performance such as witness memory; the other is that almost half of the research on memory deals with the issue of mental imagery; it is noteworthy that most contributions in this domain are made by an individual author.
Lexical processing is the dominant issue in psycholinguistic research, followed by semantic and discourse processing. A good deal of studies on lexical processing are devoted to the question of lexical priming effects, a very common topic in experimental psychology that lies on the boundary between research on language perception (i.e., visual word recognition) and research on memory (i.e., factors regulating the activation and inhibition of information retrieved from memory). Psycholinguistic research on semantic processing, in turth, is closely related to the investigation of concepts and categories, which was traditionally (as it is in the present classification) assumed to be a part of the psychology of thinking and reasoning. However, inference and deductive reasoning are the major topics of research in this latter field.

Among the issues included under miscellaneous topics, there are two that need some clarification. The topic labeled theoretical psychology consists mainly of theoretical reviews or discussions about fundamental issues in modern cognitive science (e.g., consciousness, classical or symbolic vs. connectionist or subsymbolic approaches to cognition), or about the role and relevance of the cognitive approach in contemporary psychology. Another issue that has drawn some attention is the study of cognitive impairments in certain pathological conditions, such as schizophrenia, autism, and other psychopathological disorders. These studies depart from the mainstream clinical approach followed in present-day health psychology (see Sanz, this issue) in that they try to provide a cognitive account of the deficits underlying these pathologies. In this regard, they share the claims and assumptions of cognitive neuropsychology.

The distribution of research papers concerned with topics from other fields of psychology is shown in Table 3.

As Table 3 reveals, a fair amount of research is concerned with health and clinical psychology. Most of this work is discussed in the paper by Sanz (this issue), which is specifically concerned with this research area. Also, most research work in this field is focused on anxiety, stress, and related phenomena, including assessment and treatment procedures (e.g., the use of biofeedback techniques). Also worth noting is the research on areas such as developmental psychology and educational psychology. Moral and cognitive development are the targets of most studies in the former field, together with a fruitful research trend dealing with the problem of child neglect and abuse. A substantial amount of the work done in the latter field is concerned with topics such as the teaching of social sciences in instructional settings, literacy, intervention procedures in reading comprehension, and the improvement of self-esteem at school. Also worth mentioning are the neuropsychological studies about cognitive impairments in brain-damaged patients (see Herreros de Tejada \& Muñoz Tedó, this issue, for more details about this research area).

In addition, there are other more specific research topics which have flourished in the past years, namely the 
Table 3

Distribution of Papers on Other Issues by Fields and Topics: Frequency Data

\begin{tabular}{lc}
\hline OTHER ISSUES & 663 \\
Animal psychology & $5(0.7)$ \\
Applicd psychology in various domains & $5(0.7)$ \\
Developmental psychology & $67(10.1)$ \\
Acquisition of reading & 6 \\
Cognitive development & 11 \\
Moral development & 29 \\
Psychology of older petsons & 3 \\
Other issues & 18 \\
Educational psychology & $98(14.8)$ \\
Health and clinical psychology & $233(35.1)$ \\
$\quad$ Addictive behavior & 17 \\
AIDS & 13 \\
Assessment & 18 \\
Depression & 8 \\
General issues & 13 \\
Pain and palliative psychology & 14 \\
Sensory impairments & 24 \\
Stress, anxiety, and related problems & 77 \\
Psychological aid in surgery & 20 \\
Therapy and rehabilitation & 28 \\
Hunanistic psychology & $2(0.3)$ \\
Methodology & $22(3.3)$ \\
Neuropsychology & $42(6.3)$ \\
Personality and individual differences & $10(1.5)$ \\
Psychophysiology & $24(3.6)$ \\
Psychological assessment & $18(2.7)$ \\
Psychology of gender & $21(3.2)$ \\
Psychology of road safety and dtiving behavior & $39(5.9)$ \\
Social psychology & $24(3.6)$ \\
Sport psychology & $53(8)$ \\
\hline
\end{tabular}

Note. The percentages of papers of each field of "other issues" are in brackets

psychology of gender and women studies, the psychology of road safety and driving behavior, and especially, sport psychology. These issues will be analyzed in more detail in Section 5 of this paper.

As mentioned in previous sections of this paper, it was deemed interesting to include in this review information about the kind of journals in which Spanish researchers on basic psychology publish their work. Accordingly, a subset of the total amount of published items comprising only journal articles and reports was selected from our database in order to classify them by the journals, both national and international, where they had been published during the 1989-1998 decade. This subset of items amounts to 1,493 articles. Four categories were established for this purpose, two for journals in a foreign language, and the other two for Spanish-written journals. Each of these categories was further divided into two groups of journals, according to the main topics covered by them: one group of journals -labeled General publications- included those journals devoted to general topics in psychology, publishing experimental studies and/or covering various fields of cognitive science (linguistics, philosophy of mind, computer science, neuroscience, and cognitive psychology). The rest of the journals was included in a miscellaneous group of publications that covers the topics listed in Table 3 excluding neuropsychology and psychophysiology. The number of works in the former group was 1,124 (75\%), whereas that of the latter group was $369(25 \%)^{3}$.

The figures presented in Table 4 provide information about the number of papers published in each of the previously mentioned categories of journals. The journals classified under the group of general publications in a foreign language (Table $4 \mathbf{a}$ ) amount to 84 different journals, with 267 articles. However, Table $4 a$ lists only the 35 most prominent journals of this group; the journals qualified as most prominent are those that satisfy at least one of the following two criteria: (1) achieving a minimum score in citation index surveys; and (2) supplying a certain amount of publications by Spanish basic psychology authors to the general database. The 35 journals thus selected appear in alphabetical order, together with their corresponding number of articles. The journals that belong to the group of miscellaneous publications in a foreign language (Table 4b) made up a total of 55, with 92 articles. Only one journal of this group published more than 5 articles by Spanish researchers from basic psychology (the Joumal of Personality and Individual Differences, with 8 articles). Consequently, they are listed by thematic categories, instead of journal names. As for the journals in Spanish listed in Table 4 , there were 33 in the general category, with 861 articles, and 81 in the miscellaneous category, with 273 articles. Within the former category, there are 7 joumals that concentrate most of the published work (646 out of 861 papers, which amounts to $75 \%$ of the published items). Thus, Table $4 c$ shows only the figures for these 7 topmost joumals. Similarly, there are 5 miscellaneous journals written in Spanish (out of the 81 in this category) that account for $46.69 \%$ of the published articles (127 out of 273 ). Table $4 \mathrm{~d}$ lists only the figures for these 5 journals.

\footnotetext{
3 These figures do not include the published research on experimental and cognitive psychology by authors from other areas that is described in Section 4. Interestingly, a substantial amount of this research work has achieved a very successful outlet in prestigious international journals.
} 
Table 4

Distribution of papers by journals

4a. List of 35 English-Written Journals with Basic Psychology Papers by Spanish Authors

GENERAL PUBLICATIONS

267 papers

Acta Psychologica

$7(0.596)$

Animal Learning and Behavior

$6(1.471)$

Annals of the New York Academy of Sciences

2

Behavioural Brain Research

3

The Behavioral and Brain Sciences

Behavior Research Methods, Instruments and Computers

Brain and Language

British Journal of Psychology

Bulletin of the Psychonomic Society

Cognition

Cognition and Emotion

Cognitive Neuropsychology

Cortex

Discourse Processes

European Journal of Cognitive Psychology

International Journal of Psychology

Journal of Cognitive Neuroscience

Journal of Experimental Psychology: Animal Behavior Processes

Journal of Experimental Psychology: Applied

Journal of Experimental Psychology: Human Perception and Performance

Journal of Experimental Psychology: Learning, Memory and Cognition

Journal of Memory and Language

Journal of Mental Imagery

3

Journal of Psycholinguistic Research

Language and Cognitive Processes

Learning and Motivation

Memory and Cognition

Perception and Psychophysics

Perceptual and Motor Skills

Psychonomic Bulletin and Review

Psychophysiology

Quarterly Journal of Experimental Psychology: Comparative and Physiological Psychology (B) 
4b. Categories of Miscellaneous Journals in a Foreign Language with Papers by Spanish Basic Psychology Authors

\begin{tabular}{lcc}
\hline MISCELLANEOUS PUBLICATIONS: & 92 papers \\
& Journals & Papers \\
Developmental Psychology & 5 & 12 \\
Educational Psychology & 11 & 14 \\
Health and Clinical Psychology & 16 & 25 \\
Pharmacology & 3 & 9 \\
Other topics & 21 & 32 \\
\hline
\end{tabular}

Note. The figures give the number of journals per category followed by the number of papers in each.

4c. List of the 7 Topmost Spanish-Written Journals Publisting Papers by Spanish Basic Psychology Faculty

\begin{tabular}{lc}
\hline GENERAL PUBLICATIONS: & 861 papers \\
Anuario de Psicología & 67 \\
Cognitiva & 56 \\
Estudios de Psicología & 50 \\
Psicológica & 63 \\
Psicothema & $51\left(0.292^{4}\right)$ \\
Revista de Historia de la Psicología & 249 \\
Revista de Psicología General y Aplicada & 110 \\
& Total: 646 papers \\
26 other journals: & Total: 215 papers \\
\hline
\end{tabular}

Note. The figures show the number of articles per journal.

A brief description of the Spanish journals included in Tables $4 \mathrm{c}$ and $4 \mathrm{~d}$ seems in order for obvious reasons. The oldest of Spanish publications on academic psychology is Revista de Psicología General y Aplicada [Journal of General and Applied Psychology]. As its name suggests, this is a widescope joumal that publishes both basic research and applied work, and offers a wide coverage of issues and topics in psychology. The journals Cognitiva [Cognitive], Estudios de Psicología [Psychology Studies], Psicológica [Psychological], and Psicothema [Psychotopic] began to be published in the eighties, in an attempt to meet the demands of the increasing specialization of psychological disciplines and the boost of research activities in different areas of psychology. Estudios de Psicologia and Psicothema are perhaps more comprehensive in their choice of topics and approaches, whereas Cognitiva is somewhat biased towards a cognitive outlook (as its name clearly indicates), and Psicológica is mainly oriented towards experimental work and methodological issues. Lastly, Revista de Historia de la Psicología [Journal of the History of Psychology] is specialized in historical studies of psychological topics, and, as the figures in Table $4 c$ reveal, it far exceeds the other joumals in the number of papers published by faculty members of Spanish departments of Basic Psychology. This 4d. Categories of 5 Topmost Miscellaneous Spanish-Written Joumals with Papers by Spanish Basic Psychology Authors

\begin{tabular}{lc}
\hline MISCELLANEOUS PUBLICATIONS: & 273 papers \\
Análisis y Modificación de Conducta & 28 \\
Ansiedad y Estrés & 27 \\
Infancia y Aprendizaje & 38 \\
Revista de Psicología del Deporte & 16 \\
Revista de Psicología de la Educación & 18
\end{tabular}

Total: 127 papers

76 other journals:

Total: 146 papers

Note. The figures show the number of articles per journal.

is a clear indication of the strong bias toward this research area in this field of psychology.

As for the joumals listed in Table 4d, two of them are specialized in health and clinical psychology from different angles: Análisis y Modificación de Conducta [Behavior Analysis and Modification] takes a behavioral approach, and Ansiedad y Estrés [Anxiety and Stress] is specifically restricted to the investigation of these issues, whereas the Revista de Psicologia de la Educación [Journal of Educational Psychology] is concerned with educational psychology from a broad perspective, and Infancia y Aprendizaje [Childhood and Learning] covers various topics in developmental psychology from a predominantly cognitive point of view. The Revista de Psicología del Deporte [Journal of Sport Psychology] deals with basic and applied research in the area of sport psychology, a rapidly growing field of research in Spain in the last few years.

Interestingly, the papers published in the Spanish-written general subgroup of publications (see Table $4 \mathrm{c}$ ) tend to be concentrated in a limited number of journals; in contrast, the papers published in foreign journals, either general or miscellaneous, as well as those published in Spanish miscellaneous publications tend to be much more scattered. In order to provide information about this distribution, an index of the number of published papers by number of journals was computed, by dividing the former by the latter. These data are shown in Table 5.

Table 5

An Index of the Distribution of Papers by Journals in Different Categories

\begin{tabular}{llrc}
\hline Journals & Language & $\begin{array}{c}\text { Articles } \\
\text { /journals }\end{array}$ & Papers by journals \\
\hline General & Foreign & $263 / 84$ & 3.13 \\
& Spanish & $861 / 33$ & 26.09 \\
Miscellaneous & Foreign & $96 / 56$ & 1.71 \\
& Spanish & $273 / 81$ & 3.37 \\
\hline
\end{tabular}

4 This is the only Spanish journal of experimental psychology that appears in the journal rankings of the JCR. 
A comparison of these distributions was carried out by means of chi-square analyses, yielding the following results: (a) when comparing the distribution of papers published in foreign versus Spanish general journals, it turns out that the papers published in Spanish journals are significantly more concentrated in fewer journal titles than those published in foreign journals, $\chi^{2}(1)=123.27, p<.0001$; (b) the same trend, although more attenuated, was found for papers published in miscellaneous journals, $\chi^{2}(1)=9.43, p<.001$; (c) when looking at the distribution of papers published in Spanish general versus miscellancous journals, it was found that the papers published in general journals are concentrated in fewer different journals than those from the miscellaneous group of publications, $X^{2}(1)=112.52, p<.0001$; (d) a similar trend was observed, to a lesser degree, for papers published in foreign journals, $\chi^{2}(1)=8.35, p<.001$.

An interesting piece of information that cannot bc inferred from the above figures is the degree of pervasiveness of Spanish basic psychology research in the academic psychology community both at the national and international levels. A rough and indirect estimation of this may be made by computing the amount of published work by Spanish researchers in different kinds of media. On these grounds, a comparison can be drawn between research groups from different Basic Psychology units and departments across Spanish universities in terms of their relative contribution of research papers to relevant journais. In addition, this information may be used to rank Basic Psychology units and departments from different universities according to the impact of their research work in national and foreign publications.

Obviously, this information must be laken with extreme caution. First, for reasons already mentioned in Section 2 of this paper, the database on which the present counts and computations are based represents the actual research work done in the field of basic psychology in Spain only to a limited extent. Second, the assessment of the impact of research is based exclusively on quantitative data, which precludes any judgment about the relevance or the quality of the research work analyzed. Third, and most important, the impact measure used in this review is based on an analysis of the frequency of published articles in a subset of psychology journals, Spanish and international. The selection criteria for these journals (which are those listed in Tables $4 a$ and $4 c$ above), is by no means free from possible criticisms. Nevertheless, these criteria are wholly transparent and, in my view, reasonable: The journals were selected by picking out those pertaining to the fields of general, experimental and cognitive psychology, ranking higher in citation indexes, and/or including a fair amount of papers published by Spanish authors.

First, I will analyze the impact of research on experimental and cognitive psychology by Spanish authors at an intemational level. The data shown in Table 6 include information about

Table 6

Impact of Spanish Basic Psychology Research (Grouped by Universities) in 34 Relevant Intenational Joumals of General, Experimental and Cognitive Psychology

\begin{tabular}{|c|c|c|c|}
\hline University & No. of appearances as authors & No, of faculty & Papers by author \\
\hline Universidad de la Laguna (Tenerife) & 40 & 11 & 3.63 \\
\hline Universidad de Granada & 36 & 11 & 3.27 \\
\hline Universidad de Almería & 12 & 4 & 3 \\
\hline Universidad de Santiago de Compostela & $27^{\mathrm{a}}$ & 10 & 2.7 \\
\hline Universidad de Oviedo & 19 & 9 & 2.11 \\
\hline Universitat Rovira i Virgili (Tarragona) & 6 & 3 & 2 \\
\hline Universitat de liles Balears (Majorca) & 10 & 6 & 1.66 \\
\hline Universitat de Barcelona & 23 & 21 & 1.09 \\
\hline Universidad de Málaga & 5 & 6 & 0.83 \\
\hline $\mathrm{UNED}^{\mathrm{b}}$ & 13 & 17 & 0.76 \\
\hline Universidad del País Vasco (Basque Country) & 3 & 5 & 0.6 \\
\hline Univerșidad Autónoma de Madrid & 10 & 21 & 0.47 \\
\hline Universidad de Salamanca & 3 & 7 & 0.43 \\
\hline Universidad Complutense de Madrid & 14 & 35 & 0.4 \\
\hline Universidad de Sevilla & 3 & Il & 0.16 \\
\hline Universidad de Valencia & 5 & 19 & 0.26 \\
\hline Universidad de Vigo & 1 & 4 & 0.25 \\
\hline Universidad de Murcia & 1 & 6 & 0.16 \\
\hline Universitat Autonoma de Barcelona & 2 & 16 & 0.12 \\
\hline
\end{tabular}

23 of these appearances are by the same author

${ }^{b}$ Universidad Nacional de Educación a Distancia (similar to the Open University in Britain). 
19 out of 27 Basic Psychology units and departments from Spanish universities. This information refers to the number of times that individual faculty members of Basic Psychology units and departments appear as authors (or co-authors) in papers published in the 34 journals selected as most relevant to the field. Therefore, the total figures do not represent the net amount of papers published, but rather the total sum of appearances of researchers as authors of published papers.

A similar count as the former was carried out for Spanish authors appearing in 7 relevant national journals in the field see Table $4 c$ ). The results from 22 Basic Psychology departments and units are shown in Table 7.

A superficial glance at these two tables reveals an interesting fact. Four of the universities with greater impact in international journals (the University of Almeria, the University of Granada, the Universty of Oviedo, and the University of Santiago de Compostela) are ranked much lower in their national-level impact. Conversely, three universities that rank low on international impact (the Autonomous University of Barcelona, the University of Murcia, and the University of Valencia) have a comparatively high share of papers in national publications. This fact might be taken as an indirect reflection of the research trends and interests of specific research groups on basic psychology from different universities. By way of an example, the proportion of papers concerned with issues about the history of psychology, which are virtually confined to the Revista de Historia de la Psicología (see above), amount to $90 \%$ of the papers published by faculty members from the University of Murcia in Spanish journals, and $71.5 \%$ of those published in Spanish journals by researchers from the University of Valencia.

It has been explicitly acknowledged that the figures shown in Tables 6 and 7 might misrepresent -as they indeed do in some cases- the amount of published work of certain research groups at particular universities, especially departments of Basic Psychology, part of whose research activities are displayed in fields other than general, experimental and cognitive psychology. This appears to be the case of the Autonomous University of Barcelona, a substantial amount of whose research work is concerned with health and clinical psychology, the Autonomous University of Madrid, where a good deal of research work falls within the field of developmental and educational psychology, and the Complutense University of Madrid. In this latter case, research on experimental and cognitive psychology is carried out in several departments, and the research work by basic psychology people is somewhat disseminated over a wide range of topics (health and clinical psychology and neuropsychology, among others).

Table 7

Impact of Spanish Basic Psychology Research (Grouped by Universities) in 7 Relevant National Journals of General, Experimental and Cognitive Psychology

\begin{tabular}{|c|c|c|c|}
\hline University & No. of appearances as authors & No. of faculty & Papers by author \\
\hline Universidad de Valencia & 207 & 19 & 10.89 \\
\hline Universidad de Murcia & 62 & 6 & 10.33 \\
\hline Universitat de Illes Balears (Majorca) & 61 & 6 & 10.16 \\
\hline Universitat Autónoma de Barcelona & 88 & 16 & 5.5 \\
\hline UNED & 80 & 17 & 4.7 \\
\hline Universidad de la Laguna (Tenerife) & 51 & 11 & 4.63 \\
\hline Universidad de Sevilla & 46 & 11 & 4.18 \\
\hline Universidad Complutense de Madrid & 132 & 35 & 3.77 \\
\hline Universidad Autônoma de Madrid & 71 & 21 & 3.38 \\
\hline Universitat Jaume I (Castellón) & 16 & 5 & 3.2 \\
\hline Universidad de Almería & 12 & 4 & 3 \\
\hline Universidad de Coruña & 3 & 1 & 3 \\
\hline Úniversidad del País Vasco (Basque Country) & 15 & 5 & 3 \\
\hline Universidad de Vigo & 12 & 4 & 3 \\
\hline Universidad de Granada & 32 & 11 & 2.9 \\
\hline Universidad de Santiago & 29 & 10 & 2.9 \\
\hline Universidad de Oviedo & 24 & 9 & 2.66 \\
\hline Universidad de Salamanca & 18 & 7 & 2.57 \\
\hline Universitat de Barcelona & 53 & 21 & 2.52 \\
\hline Universidad de Málaga & 12 & 6 & 2 \\
\hline Universitat Rovira i Virgili & 6 & 3 & 2 \\
\hline Universidad de Castilla-La Mancha & I & 3 & 0.33 \\
\hline
\end{tabular}


Description of the Main Research Trends on Experimental and Cognitive Psychology

This section provides a review of the main research trends in the fields of experimental and cognitive psychology, as reflected in published work by faculty members of departments and units of Basic Psychology across Spanish universities. These research trends will be grouped according to the fields and topics listed above in Tables 2 and 3, with no mention of their authors' affiliation. A sample of representative papers from each of the research trends will also be provided. Given the considerably wide coverage of this review, a detailed analysis of the specific aims, methods, or results of the research work under review is beyond the scope of this paper.

\section{Attention}

The main body of research in this field is concerned with visual attention. There are six research trends on this topic that are worth noting. First, some researchers have focused their work on the variables affecting the decrease of vigilance in various sorts of attentional tasks (Blanco, Lamas, \& Álvarez, 1992). Another research trend has investigated the issue of visual search and spatial visualization. Among the topics investigated in this connection are the roles of practice and of different perceptual variables on performance in visual search tasks (Carrasco, Ponte, Rechea, \& Sampedro, 1998), the examination of sex differences in visuospatial abilities (Delgado $\&$ Prieto, 1996), and the development of computerized procedures for the assessment of these abilities (Prieto, Carro, Pulido, Orgaz, Delgado, \& Loro, 1996).

A third research trend deals with the allocation of attentional resources and the depth of processing in parafoveally presented visual stimuli (Fuentes \& Tudela, 1992; Fuentes \& Ortells, 1993; Ortells \& Tudela, 1996; Ortells, Tudela, Noguera, \& Abad, 1998). A fairly extensive research work has been devoted to the study of the processes involved in rapid serial visual presentation tasks. Among the issues examined are the role of perceptual and conceptual variables and the influence of automatic and strategic factors in these processes (Barriopedro \& Botella, 1998; Botella, García, \& Barriopedro, 1992). A fifth research trend on visual attention, which takes a somewhat clinical approach, is concemed with the study of inspection time of visual stimuli from different perspectives, such as its relation to psychometric measures of intelligence, or its electrophysiological correlates (Vigil, Ferrando, \& Pueyo, 1993). Lastly, some authors have studied the influence of alcohol consumption on selective attention, divided attention, and attention shifting (Rosselló, Munar, Arias, \& Justo, 1996; Roselló, Munar, Justo, \& Arias 1998).

\section{Emotion}

Research on emotion has been quite scarce from a basic psychology perspective. The only case worth mentioning is a series of studies on the influence of emotional states (e.g., anxiety, happiness) or personality traits (e.g., impulsiveness, extraversion) on cognitive and behavioral inhibition (Avila \& Parcet, 1997). This work should be properly viewed as an effort to integrate basic research and clinical approaches. Most research on affect and emotion, however, has been carried out entirely under other approaches (mainly personality and individual differences, and health psychology), and will be addressed in Section 5 (see Sanz, this issue, for further details).

\section{History of Psychology}

The review of research work on this field has been particularly cumbersome for a number of reasons. First, the themes and topics covered under this field are virtually countless, as has been mentioned in previous sections of this paper. In addition, the research trends are much more difficult to categorize and individuate here than in other areas of basic psychology. Likewise, research on the history of any scientific discipline is more theoretical in nature and uses wholiy different methodologies, when compared to other areas of empirical enquiry. In this review, I have opted for a thematic analysis, resorting to methodological considerations wherever appropriate. This has led to the following picture.

To begin with the most extended research trends in this area, I should mention a vast number of works concerned with the analysis of concepts, subjects, issues, schools of thought, and authors of historical interest within psychology in terms of their gross impact on published materials. The approach followed in these works is quantitative, and as such, it has been dubbed bibliometric analysis. The bibliometric approach has been used to analyze a wide range of topics, including the following: the state of the art in psychology at a general, national, regional or local level, as seen through particular publications (e.g., Artieta \& Ferrándiz, 1991; Bañuls \& López Latorre, 1991; Carpintero \& Tortosa, 1996; Díez, Pérez-Delgado, \& Mestre, 1990; González, Carpintero, Peiró, \& Tortosa, 1990; Lafuente \& Ferrándiz, 1991; Pedraja,Vera, \& Quiñones, 1996; Pérez-Delgado, Mestre, \& García-Ros, 1990; Saiz \& Saiz, 1994; Vera, Quiñones, Sánchez, \& Pedraja, 1991), the evolution and development of psychological schools and paradigms (e.g., psychoanalysis, Gestalt psychology, behaviorism, cognitivism) and their influence in Spanish psychology (Lafuente \& Ferrándiz, 1992; Saiz, Saiz, Mülberger, \& Gabucio, 1991), the impact of particular authors in academic psychology (Carpintero, Tortosa, \& Peiró, 1990; Pérez-Garrido, Tortosa, \& Calatayud, 1997; Tortosa, Calatayud, \& Pérez-Garrido, 1992, 1996; Zabildea, Tortosa, \& Carpintero, 1989), and the relevance of specific research topics (e.g., studies on the psychology of gender -as in Mestre, Martí, \& Samper, 1996- moral psychology -as in Pérez-Delgado \& Mestre, 1993- or psychophysiological research -as in Sánchez-Hernández, Padraja, Quiñones, \& Martínez, 1996). 
Aside from the bibliometric approach, topics such as the ones just mentioned and many others as well have been examined from different perspectives by Spanish historians of psychology. One is the analysis and discussion of the historiographical research methods used in the field, and the reflections on historical analysis as a subject matter in Psychology (Rosa, 1993, 1994; Rosa, Huertas, Blanco, \& Montero, 1993; Ruiz, Sánchez, \& Casa, 1998). Also worth noting is a group of studies devoted to unravelling the historical foundations and philosophical underpinnings of modern schools of thought in psychology, and of a number of central concepts in psychological theorizing. These cover a wide range of issues, such as the origins of behaviorism (Fuentes \& Robles, 1992; Gondra, 1992), the foundations of the Soviet socio-historic school (Huertas, Rosa, \& Montero, 1991), the historical analysis and clarification of the mechanism of natural selection (Sánchez \& Fernández, 1990), or the vicissitudes of the introspective method in psychology (Quintana, 1990). Of particular interest are numerous studies that explore the contribution of Spanish classical authors (from philosophers such as Feijóo and Ortega y Gasset, to physicians such as Germain, Gómez Pereira, or Mira i López) to the development of psychology in our country (Bandrés, Campos, \& Llavona, 1994; García, Fuentes, \& Carpintero, 1993; Martí, Tortosa, \& Carpintero, 1992). Lastly, the evolution of academic and professional psychology in Spain has also been the target of various sorts of studies: for instance, those focusing on the development of Spanish psychological institutions over the years (Encinas \& Rosa, 1990), or those that report general overviews of Spanish psychology (e.g., Prieto, Fernández-Ballesteros, \& Carpintero, 1994) intended for international readership (of which the collection of articles included in this issue is but one more example).

An important contribution to the development of research in this flourishing area are the annual meetings of the Spanish Society for the History of Psychology, which provide an opportunity for Spanish researchers on the field to discuss and exchange ideas about their subjects of interest. These meetings gather researchers from various universities across the country, with some prominent invited speakers from abroad, and are organized by a different university every year.

\section{Learning}

Research on learning processes appears to be mainly concentrated in the areas of classical Pavlovian and operant conditioning, with $90 \%$ of the published work. The main research trends under the classical conditioning approach can be summarized as follows. First, the issue of aversion learning in rats has generated a large amount of work, particularly regarding the role of different factors on the development of taste aversion, such as induced brain lesions, chemical substances, or variations in the scheduling of stimuli (Aguado, Brugada, \& Hall, 1997; Aguado, Hall,
Harrington, \& Symonds, 1998; Gallo \& Cándido, 1995; López-Ramírez \& Aguado, 1992; Loy, Álvarez, Rey, \& López-Ramírez, 1993). In this connection, the issue of latent inhibition has also been addressed as related to different learning conditions and variables (Aguado, Symonds, \& Hall, 1994; Álvarez \& López-Ramírez, 1993). Another issue that has roused some concern is the variables affecting the memory of the duration of conditioned stimuli (Rosas \& Alonso, 1997). Turning to a different topic, I should also mention some research work on the susceptibility of skin conductance responses to modification by classical and instrumental conditioning procedures (Marcos, 1998).

One can ascertain at least four different research trends within the field of operant conditioning. First, a substantial amount of work has been devoted to the issue of learned helplessness under various approaches. One approach to this issue has been to examine the role of stimulus feedback and predictability, among other factors, on learned helplessness in rats in appetitive contexts (Ferrándiz \& Pardo, 1990; Ferrándiz \& Vicente, 1997). A different issue that also has some bearing on learned helplessness is the study of the variables affecting contingency judgments and the prediction of events in humans (Bennett, Maldonado, \& Mackintosh, 1995; Martos, Catena, Maldonado, \& Ramírez, 1995), a research area with relevant applications in the prevention and treatment of depression, and the assessment of witness reports at courts of law. A second research trend on associative learning concerns the effects of feeding schedules and drugs on induced drinking in rats (Lamas \& Pellón, 1997; Pellón \& Blackman, 1992). The issue of avoidance learning has also been the subject matter of some research work, again in connection with the effects of drugs (Morales, Torres, Megías, \& Cándido, 1992; Torres, Morales, Cándido, \& Maldonado, 1996) and other variables such as feedback duration (Cándido, Maldonado, \& Vila, 1991). Lastly, the topic of perceptual learning has been extensively studied, especially in maze-discrimination tasks with rats (March, Díez-Chamizo, \& Mackintosh, 1992; Rodrigo, DíezChamizo, McLaren, \& Mackintosh, 1994).

Research on learning from a cognitive standpoint lags far behind the conditioning approaches just examined. Two independent and quite dissimilar research topics stand out in this area. One is the issue of learning without awareness or implicit learning. Research on this topic has focused on the role of attention in the implicit learning of sequences, and on the measures used in the assessment of implicit learning (Jiménez, Méndez, \& Cleeremans, 1996; Méndez \& Jiménez, 1998). The other research trend builds on a classical research theme in educational psychology, namely the abilities of experts and novices in various performance domains. Research on this topic covers at least three different areas, all related to leaming processes: proportional reasoning (Sanz, Pozo, Pérez, \& Gómez-Crespo, 1996), text comprehension (León \& Carretero, 1992), and learning of geographical maps (Postigo \& Pozo, 1998). 


\section{Memory}

A review of research on memory by Spanish basic psychology faculty reveals a striking picture. The reason lies not only -nor principally-in the relatively scarce amount of work done in this area, but also in the way this research work is distributed. First of all, there are no more than four or five different research teams with enough published work to qualify for appearance in this report. First, an applied area of memory research that has been investigated is witness memory. Two outstanding issues that emerge from this work are the relevance of cognitive interviews in retrieving information from witnesses (Davies \& Alonso-Quecuty, 1997), and the detection of lies in witness reports (Hernández-Fernaud \& Alonso-Quecuty, 1997). A related research topic concerns the distinction between perceived and imagined memories (Manzanero \& Diges, 1994). The second research trend in the field of memory deals with mental imagery. This research area lies on the boundary between perception and memory, and, as in the case of the work reported here, has projections on other areas of psychological research as well. The research on this topic reviewed for the present report covers an extensive body of work carried out by one research team -with more than 50 papers published in the 1989-1998 decade- that revolves around two main issues: analysis of the perceptual, semantic, and emotional properties of the materials (i.e., words) used to elicit images (Campos, 1995), and the relationship between mental imagery and creative thinking (Campos \& González, 1994).

Turning to other areas in memory research, there is some interesting work on basic processes in memory that deserves to be reported in this review. This work is concerned with at least two differet topics. One is the dissociation between implicit and explicit memory, where the topics examined are the degree of elaboration of memories in various tasks (Pitarque, Algarabel, \& Meseguer, 1992), and the possibility to perform connectionist simulations of these dissociative effects (Pitarque, Ruiz, \& Algarabel, 1995). The other concerns the effects of concreteness on memory performance, and addresses a number of factors that are claimed to underlie such effects (Cuevas \& Ruiz-Vargas, 1992; RuizVargas \& Cuevas, 1996).

Lastly, an issue that is far removed from the research trends reviewed so far is the question of context effects on recall, which has been studied mainly in the visuo-spatial domain (Alonso \& Fernández, 1997).

\section{Motivation}

Despite its being one of the core disciplines of basic psychology programs and syllabuses in Spain, research on motivation does not seem to have attracted much attention among Spanish researchers. This is, at least in part, probably due to the fact that motivation is a typically interdisciplinary field of research in psychology, a meeting ground for disciplines like basic psychology, psychobiology and social psychology. One exception worth mentioning concerns research that attempts to model motivationally oriented behavior in social settings from an approach based on fuzzy logic (Barberá \& Albertos, 1994). This same group of researchers has addressed the issue of achievement motivation as related to gender (Barberá \& Cantero, 1996). I will return to the latter research topic in Section 5.

\section{Perception}

Looking at the materials collected for this review, it turns out that most research on perception in Spain comes from research teams from the area of methodology of the behavioral sciences. These research groups, alongside others from basic psychology, have contributed a substantial amount of published work predominantly focused on visual perception. This research has touched upon various topics. Ranging from research on low-level processes to the study of higher processing levels in vision, one finds the following topics of interest. The investigation of psychophysical responses of visual channels in early stages of visual processing is a relevant research trend in this area. This research addresses questions such as the sensitivity and tuning of the channels to different properties of visual stimuli, or the use of mathematical models to account for different visual phenomena (García-Pérez \& Sierra-Vázquez, 1996; Sierra-Vázquez \& García-Pérez, 1995). Another topic of interest is shape and object perception in 2- and 3dimensional displays, with a comparison of the visual and haptic modalities (Ballesteros, Manga, \& Reales, 1997, 1998). A further research trend deals with the role of certain geometrical properties of context on the recognition of visual stimuli (Crespo, Fernández, \& Prado, 1994). A somewhat related issue concerns the relevance and relative dominance of global and local information in visual perception, as related to various factors: retinal position or eccentricity, exposure duration (Luna \& Merino, 1998; Merino \& Luna, 1997), stimulus density (Arnau, Blanca, \& Salvador, 1992), or hemispheric differences (Blanca, Zalabardo, GarcíaCriado, \& Siles, 1994). The role of typicality in object perception and recognition has been studied in conjunction with the issue of figure-ground perceptual organization (Beltrán \& Herrando, 1995). A particular extension of this work deais with the learning of perceptual organization abilities at early ages (Salavert, Pelegrina, \& Beltrán, 1998).

In addition to this research on basic processes in visual perception, there are two more research trends on perception that stand on the boundary between basic and applied psychology. One of them deals with color perception and its impairments (e.g., different forms of color blindness). A recent development of this research trend is concerned with the assessment of color-perception dysfunctions in children (Lillo, 1998). The second research trend comprises a number 
of studies on spatial perception and representation in blind persons. This work has a twofold objective: first, to discuss the cognitive bases of spatial representation in blind children, and the methods employed to study them (Huertas \& Ochaita, 1992); and second, to analyze the effects of blindness on various aspects of childrens' social and cognitive development, and their particular educational needs (Ochaita \& Rosa, 1990).

\section{Psycholinguistics}

Psycholinguistics is a thriving field of research in Spanish psychology, especially from the late eighties onwards. There has been a wide coverage of issues in this field, ranging from studies on language acquisition to research on language processing in adults and language impairments. However, most psycholinguistic research done by basic psychology faculty has concentrated on language comprehension processes. The main topics within this research area are the study of word recognition processes, mainly in the visual modality, the investigation of discourse and text comprehension in reading tasks, and, to lesser extent, the study of syntatic parsing in sentence processing. Studies on visual word recognition have focused on a number of different variables, both linguistic and nonlinguistic, affecting lexical access operations. Among the linguistic variables investigated are the orthographic features -such as segmentation in syllabic units (Bradley, Sánchez-Casas, \& García-Albea, 1993; Carreiras, Perea, \& Grainger, 1997; Domínguez, Vega, \& Cuetos, 1997; Perea \& Gotor, 1996), the morphological structure (García-Albea, Sánchez-Casas, \& Igoa, 1998), and the semantic characteristics of words (Cañas \& Bajo, 1994, 1996; Mayor \& González-Marqués, 1994; Perea \& Gotor, 1997). As for the nonlinguistic variables examined, one may cite repetition effects in priming (Algarabel \& Dasi, 1994), set size (Algarabel \& Ruiz, 1995), or stimulus onset asynchronies (Algarabel \& Dasi, 1997; Mayor \& GonzálezMarqués, 1994). Work on discourse and text comprehension processes has been carried out in various domains, such as the interpretation of anaphoric pronouns (Carreiras, Garnham, \& Oakhill, 1993; Garnham, Oakhill, Ehrlich, \& Carreiras, 1995), the time course of inferences in text processing (Gutiérrez-Calvo \& Castillo, 1998), the role of mental models in text comprehension (Vega, 1995), the representation of emotions in the reading and comprehension of texts (Vega, Díaz, \& León, 1997), and the use of different sorts of information in the comprehension and recall of newspaper texts (León, 1997). The study of parsing in Spanish has also been a fairly relevant topic in recent psycholinguistic research. Most work in this area has dealt with the issue of parsing strategies (Carreiras \& Clifton, 1993; Gilboy, Sopena, Clifton, \& Frazier, 1995; Igoa, Carreiras, \& Meseguer, 1998; Mitchell, Cuetos, Corley, \& Brysbaert, 1995).

In addition to the major research topics reviewed thus far, there is some research work to report in other areas of adult language processing. One of them is speech perception, where a number of studies have dealt with the role of syllabic units in auditory word recognition (Pallier, SebastiánGallés, Dupoux, \& Mehler, 1998; Pallier, Sebastián-Gallés, Felguera, \& Christophe, 1993; Sebastián-Gallés, Dupoux, Seguí, \& Mehler, 1992), a topic of concern to researchers on visual word recognition as well (see above). Another group of studies worth mentioning are those that have examined basic processes in reading, in order to explore the pathways used for lexical access in reading tasks. An interesting debate in this field of research concerns the issue of whether phonological information is used to recognize and understand written words in an orthographically shallow language such as Spanish, or word identification processes are based on analogical information (Gutiérrez-Calvo \& Castillo, 1995; Sebastián-Gallés, 1991; Valle, 1996). Lastly, some research has also been directed at the study of phonological encoding in language production, both through experimental procedures (Costa \& Sebastián-Gallés, 1998), and by analyzing the patterns of spontaneous speech errors (Viso, Igoa, \& García-Albea, 1991).

Moreover, there are a few other lines of psycholinguistic research beyond adult language processing. These include a number of studies on language acquisition at various levels and from different perspectives (for more information, see the review of developmental and educational psychology by Sánchez-Miguel and García-Sánchez in this issue). A very promising research trend in this area is the study of speech perception in infants from monolingual and bilingual backgrounds (Bosch \& Sebastián-Gallés, 1997). Another group of studies carried out by López-Omat and co-workers focuses on the unfolding of grammatical representations in early language acquisition stages (López-Ornat, 1997). Lastly, the study of the development of referential communication abilities in children (Girbau \& Boada, 1996; Martínez, Foms, \& Boada, 1997 ) is another research topic in spanish psycholinguistics that deserves to be included in this brief review.

There are some other topics that are unquestionably related to the mainstream psycholinguistic research reported in the last three paragraphs, but will be addressed in other sections of this paper. These concern the investigation of language impairments, including selective language deficits -both developmental and acquired through brain injury- and linguistic anomalies associated with more general cognitive disturbances, and will be addressed under miscellaneous topics in this section, or in the neuropsychology paragraph in Section 5.

A relevant contribution to the development of psycholinguistic research in Spain in recent years is the Symposium on Psycholinguistics, a biannual meeting that began in 1993 and brings together Spanish researchers in the field and some foreign invited participants. The increasing number of contributions to this symposium is an indication of the growing interest of this field of inquiry in our country. 


\section{Thinking and Reasoning}

Although it is one of the most credited areas in cognitive and experimental psychology, research on thinking and reasoning does not have many practitioners in Spain and thus has remained somewhat isolated from other research areas in cognitive psychology, with a comparatively low amount of published work. It might be argued, however, that this low rate of research on reasoning could merely reflect a classification bias on the part of this reviewer, as at least part of the work bearing on text processing or even cognitive learning reported previously might as well fall under the category of reasoning processes (see the work by López, Shanks, Almaraz, \& Fernández, 1998, as a case in point). In fact, it is reasoning processes that make for most of the published research work in this area. Deductive reasoning, the most extensively investigated issue in this field, has addressed traditional issues such as the role of context (González \& Arias, 1995), or the influence of contents on reasoning (Sanz, Pozo,, Pérez, \& Gómez-Crespo, 1996; Valiña, Seoane, Feraces, \& Martín, 1998).

Another topic that has received some attention is the role of implicit theories (sometimes referred to as naive theories) in reasoning processes, especially as an aid to understanding the development of expertise in various domains (López-Manjón \& Carretero, 1993; Pozo \& Carretero, 1991). This kind of research can be seen as a bridge between basic research on reasoning and research on applied issues in educational psychgology.

Studies on concepts and categories are even more scarce, especially when compared to the enormous amount of studies on lexical processing reported in the previous subsection. By way of an example of the kind of research carried out in this area, an attempt at clarifying the organization of the human lexical-conceptual system can be found in recent work by Peraita and Malrieu (1998).

Lastly, the only research devoted to the topic of decision making has been carried out from a psychosocial perspective, which makes it somehow problematic to include such work in this section. This research deals with the biases in decision-making processes that are induced by social factors (see Arce, Fariña, \& Vila, 1996, and the discussion of this work in the review of research on social psychology by Blanco \& Corte, this issue ).

\section{Other topics}

To close this section on basic psychology research, I will give a brief account of some work pettaining to one of the categoties included in the miscellaneous group of Table 2 above, which falls under the label cognitive intpairments. As mentioned, the cognitive outlook that this research work exhibits prevents it from being assigned to any other thematic category. It encompasses the study of the cognitive and/or linguistic deficits commonly found in developmental disorders such as autism, dyslexia, or dysphasia, or in adult psychopathological conditions such as schizophrenia.

There are three issues in developmental cognitive disturbances that have generated a fair amount of published work. One is the study of some cognitive deficits that are claimed to account for a variety of symptoms found in autism, namely the severe retardation or impairment shown by autistic people in developing a theory of mind -or, to use a more general term, in their mentalistic abilities (Canal \& Rivière, 1993; Olivar \& Belinchón, 1997; Philips, Gómez, Baron-Cohen, Laa, \& Rivière, 1995). The second issue worth mentioning is the study of child dysphasia, a selective loss of grammatical abilities in language development, among Spanish-speaking language learners (Bosch \& Serra, 1997). The third issue referred to above comprises a series of studies on developmental dyslexia intended to explore some visual disorders that are supposed to underlie certain observed patterns of reading retardation in Spanish children (Defior, Justicia, \& Martos, 1996; Martos, 1995).

Research on cognitive impairments in psychopathological syndromes in adults is represented by the study of attentional deficits in schizophrenia, under the assumption that the disorders of thought found in this pathological condition can be best characterized in terms of a disturbance in controlled processes. In this view, the hallucinations suffered by schizophrenic patients (or by hallucination-prone normal subjects) might be brought about by a deficit in reality monitoring, and hence by the inability to properly establish the sources (internal vs. external) of their memories (RuizVargas, Cuevas, \& López-Frutos, 1998).

To finish this section, I would like to add a final word about the research literature reviewed so far. Most research on the aforementioned topics can be regarded as experimentat, obviously if we exclude most of the research on history of psychology. In contrast, the cognitive label can hardly be applied as liberally. For one thing, if taking a cognitive stance is seen to imply some deep commitment to a conception of the mind as a representationalcomputational device, then very little research work in basic psychology can actually claim to be cognitive by the usual standards. Therefore, it would have been misleading to regard the body of research just described as cognitive. In most instances, however, the label cognitive is no more than a conventional way to refer to a set of topics and issues that are loosely held together. In this sense, cognitive issues would encompass all psychological phenomena that can be characterized in terms of mental states and processes, and taking a cognitive approach would mean little more than being interested in human mental affairs. It is not surprising then that when, in 1997, a group of Spanish researchers on basic psychological processes (most of them from departments of Basic Psychology around the country) decided to found a research association and hold biannual meetings to exchange and discuss the results of their research work, they named it the Sociedad Española de Psicología 
Experimental [Spanish Society for Experimental Psychology], also known by the acronym SEPEX ${ }^{5}$ However, this is not the whole story to be told about Spanish research on basic psychology. To give an accurate picture of the research carried out by faculty members in this area, we need to take into account a significant amount of work on topics from other areas of psychology, including basic and applied research. The next section is intended to report the research done in these areas.

Description of the Main Research Trends on Health and Clinical Psychology, Developmental and Educational Psychology, and Several Fields of Applied Research

In order to give a clear picture of the research interests pursued by basic psychology faculty in Spain in areas that fall outside the subjects covered by basic psychology, a distinction should first be drawn between research on traditional broader domains of psychology, such as health and clinical psychology, developmental and educational psychology, psychobiology, or social psychology, on the one hand, and research on fairly specific domains in applied fields, such as the psychology of road safety and driving behavior, the psychology of gender and women studies, and sport psychology, to mention explicitly three topics that have concentrated a large amount of work by Spanish basic psychology researchers. This distinction, however, may not seem as clear cut as it is intended, for the issues investigated in the latter domains could well be classified under more general headings of the former kind.

Leaving aside these categorization problems, the truth is that the above distinction can serve as a useful guideline for expository purposes, so I shall follow it throughout the remaining part of this paper. However, one note of caution must be made: for obvious reasons, part of the information to be reported below will surely overlap with the contents of other papers of this issue. This will be particularly the case of the four general fields referred to in the last paragraph. Whenever this happens, I will refer the reader to the relevant papers of this issue that cover the information mentioned here.

\section{Health and Clinical Psychology}

The papers on health and clinical psychology published by basic psychology faculty in the 1989-1998 decade amount to more than one-third of the whole research work in areas outside basic psychological processes and history of psychology (see Table 3). The main research trends in this area are on the topics of anxiety and stress, therapy and rehabilitation procedures in a variety of domains, palliative care and psychological assistance to terminal patients and patients undergoing surgery, behavioral support of patients with AIDS, and addictive behavior of various kinds. The issue of psychological assessment, both for clinical and more general purposes, has also motivated a great deal of work. And finally, there are some other topics outside the clinical sphere, such as the study of sensory impairments (e.g., blindness), that have also attracted some researchers' attention.

The topic of anxiety has been dealt with in a variety of ways and for different purposes. Seen as a permanent emotional disturbance, anxiety has been studied with the aim of finding out its cognitive grounds (Gutiérrez-Calvo \& Cano, 1997 -see also Sanz, this issue). Anxiety has also been analyzed as a kind of state associated with particular experiences, such as tests and exams, dental surgery, or driving (Carbonell, Bañuls, \& Miguel-Tobal, 1995; Escalona \& Miguel-Tobal, 1995, Rodriguez-Saavedra \& Cano, 1995). One major issue in this regard is the assessment and remediation of emotional and psychophysiological disorders such as stress and anxiety under various situations and conditions. Both topics have been subjected to extensive research by a number of authors: the former by means of psychophysiological indicators of stress -such as palm sweating (Martínez-Sánchez, Ortiz, \& Fernández-Castro, 1998) or heart rate (Grzib, Ortega-Mata, \& Brengelman, 1993; Gutiérrez-Calvo, Szabo, \& Capafons, 1996; Palmero \& Choliz, 1991) - or by devising inventories intended to measure anxiety reactions in various situations (Bañuls, Carbonell, \& Miguel-Tobal, 1993); the latter by testing cognitive-behavioral programs conducted to alleviate emotionally unpleasant responses (Escalona \& MiguelTobal, 1996). Moreover, stress has been examined in its relation to a number of different factors, such as personality variables (e.g., Palmero, Codina, \& Rosel, 1993), stressinducing situations (Carreras \& Fernández-Castro, 1998), or immunological factors (Borrás, 1995; Borrás, Estébanez, Gudayol, Soriano, \& Bayés, 1998).

A very fruitful and indeed powerful research trend on health psychology followed by several groups around the country is the use of behavioral techniques and procedures to aid in the prevention and coping of situations involving severe diseases (such as AIDS or cancer) and some of their side effects (e.g., pain), stressful experiences such as drug abuse and other addictive conditions, or preparation for surgery. This field of applied research has come to be known by the label of behavioral medicine (for more details, see Sanz, this issue, and Bayés, 1990). Some representative examples of this work are the use of techniques based on

5 For information about this association, contact http://www.sepex.es. 
Skinner's functional analysis of behavior to assist patients with AIDS and people from different risk populations (e.g., Bayés, Comellas, Lorente, \& Viladrich, 1998), and to assess the anxiety of terminal cancer patients and aid in their adaptation to the illness (Barreto, Bayés, Comas, \& Martínez, 1996; Blasco \& Inglés, 1997). A related research trend that has been pursued from a broader perspective (i.e., with cognitive-behavioral tools) concerns the evaluation of anxiety in patients undergoing surgery (Moix, 1997), and other closely connected issues, such as the measurement of conscious activity during surgical interventions (Moix, 1996), and the effectiveness of various intervention procedures in pre- and post-surgical stages (Moix, Bassets, \& Caselles, 1998).

The study of addictive behavior from a broad cognitive perspective has been another research target in this area. Some studies on this topic have focused on the motivational grounds of alcohol abuse and the learning processes involved in addictive behavior (Mayor, Cano, Cantón, \& Sos-Peña, 1992). Other studies have focused on the role of social workers in the remediation of drug abuse and the training of specialized personnel in this area of health psychology (Mayor, 1993).

Aside from the studies on therapeutic procedures previously reported, there is also some relevant work concerned with the use of certain therapeutic procedures for specific purposes, such as biofeedback techniques in the treatment of insomnia or headaches (Choliz, 1995), and hypnosis in various emotional disorders (González-Ordí \& Miguel-Tobal, 1994); the experimental analysis of the placebo effect has been another topic of concern (Choliz, 1994).

To end this subsection, 1 will describe two entirely distinct research trends concerned with psychological assessment. One is the work carried out by Mestre and her colleagues on the development of scales and questionnaires to assess depression in children, as well as other related phenomena, particularly self-esteem (Barrio, Frías, \& Mestre, 1994; Frías, Barrio, \& Mestre, 1991). This work is part of a larger research enterprise devoted to studying a number of variables related to self-esteem and their role in childrens' performance at school, the onset of depression, and moral development in adolescents. The other research trend involving psychological assessment has been the development of expert computational systems for the diagnosis of psychopathological conditions, such as autism (Adarraga \& Zaccagnini, 1992) or depression (Cubo, Zaccagnini, \& Adarraga, 1995). This is, to my knowledge, one of the few instances, if not the only one, of applied research by basic psychology faculty in Spain that issues directly from basic research on artificial intelligence.

\section{Developmental and Educational Psychology}

Research on developmental and educational psychology has rendered about $25 \%$ of the published work in areas other than basic psychology. Moral and cognitive development are two outstanding research areas in developmental psychology. Research on moral development has supplied a series of studies on the evolution of moral values and moral reasoning in adolescence. These studies focus on several factors that are claimed to influence moral development and sociomoral reasoning, such as family background, formal education, and cognitive and affective factors (Pérez-Delgado, 1994; Pérez-Delgado \& Oliver, 1995). This research is deeply entrenched with the development of evaluation procedures and intervention strategies in moral education (Mestre \& Pérez-Delgado, 1997), and with the studies on self-esteem and depression mentioned in the last paragraph. Other studies on moral issues have been carried out from a socio-psychological perspective, by focusing on positive-valued attitudes and values such as altruistic behavior and empathy, and addressing the gap one often finds between cognitive judgments about moral issues and real actions (Etxebarría \& Caba, 1998; Fuentes, López, Etxebarría, Ledesma, Ortiz, \& Apocada, 1993).

Research on cognitive development has also gone hand in hand with applied research on education. A dominant topic of research in this area has been the development of historical knowledge and reasoning about history in adolescence, and the concomitant teaching of the social sciences in instructional settings during this period of life (Carretero, Asensio, \& Pozo, 1991; Carretero, López-Manjón, \& Jacott, 1997). These issues have been addressed from a constructivist framework. Another topic that has some bearing on both educational and clinical matters is the evolution of communication abilities during early stages of cognitive development (Sarriá \& Rivière, 1991), with special reference to the development of mentalistic vocabulary (Sotillo \& Rivière, 1997). It has been argued that the deficits underlying much of autistic behaviors might be traced back to a serious undermining of early communication skills.

The issue of child neglect and abuse and the study of mother-child interaction patterns has also been a topic of research in this area (Cerezo, d'Ocón, \& Dolz, 1996). The aim of this research is to explore sequences of behavior in mother-child exchanges, and the consequences of coercive behaviors and physical punishment on the child's emotional and cognitive adjustment.

Lastly, I will also mention some research trends on educational psychology involving the development of intervention procedures in reading comprehension. One of these research trends has focused on the learning and teaching of literacy in adults from a socio-historical perspective. This approach highlights the role of private speech in reading comprehension processes and proposes the use of dialogue as a tool in literacy teaching in the classroom (Ramírez, 1994). Another research trend in this area is concerned with the use of metacognitive skills in intervention programs designed to improve text learning and recall (González, 1997; Mateos, 1995). 


\section{Neuropsychology}

Not unexpectedly, most studies on neuropsychology have been carried out by researchers from the area of psychobiology. Accordingly, the relevant work is reported in the article by Herreros de Tejada and Muñoz Tedó (this issue). There are, however, two significant research trends on neuropsychology by basic psychology researchers that deserve to be mentioned here. One is concerned with the neuropsychology of language, and the other one with neuropsychological assessment and rehabilitation.

An interesting fact about neuropsychological research in Spain is that most studies, in particular of patients with acquired disorders of language (i.e., adult aphasics), have been published by psycholinguists or other researchers from the area of basic psychology. It is unclear whether this is just a matter of chance, or whether it occurs because language is a peculiar research area in psychology that requires specific knowledge and expertise. Research work on aphasia has rendered interesting results for the purpose of cross-linguistic comparison of the patterns of linguistic deficits in brain injured patients. This work has explored issues such as phonological dyslexia (Cuetos, Valle, \& Suárez, 1996) and agrammatism (Benedet, Christiansen, \& Goodglass, 1998; Miera \& Cuetos, 1998), among others, reporting several case studies of Spanish-speaking patients. Neuropsychological asessment and rehabilitation have also been topics of concern to researchers in this area. In addition to the adaptation of foreign tests to the Spanish population (and language), new neurolinguistic evaluation instruments have been developed by Spanish authors in recent years for instance, in areas such as mernory and language (e.g., Benedet \& Caplan, 1996). As for rehabilitation, there is one research team that has developed and tested rehabilitation procedures for various purposes and in different domains with brain injured patients: memory skills (León-Carrión, 1997a), emotional disorders (León-Carrión, 1997b), and social skills (Machuca, Carrasco, \& González, 1997).

\section{Other Issues in Applied Psychology}

As mentioned in the introduction to this section, there are three emerging fields of applied research in psychology that have developed at an increasing pace in the last decade. They are the psychology of gender, the study of road safety and driving behavior, and sport psychology. All three constitute fairly specific domains of empirical enquiry and professional practice that do not fit in any single standard discipline or field of psychology. Research on these fields is bound to be, at least ideally, an interdisciplinary kind of job.

The psychology of gender and women studies has been approached from at least two different perspectives: one is the historical evolution of gender stereotypes and women studies as they are reflected in the psychological literature (Barberá \& Pastor, 1992); and the other deals with the developmental psychology of gender from childhood to adulthood, and the relation between gender and emotional and motivational issues (Lafuente \& Barberá, 1995).

The study of road safety and driving behavior from a psychological standpoint covers a wide range of issues and topics, and has been the source of a vast number of publications in the last years in our country. The main research trends on these topics can be summarized as follows: (a) the study of drivers' allocation of attentional resources, as measured by the patterns of eye-movements (Recarte, Nunes, López, \& Recarte, 1998), and drivers' perception of speed (Lillo, 1995; Recarte \& Nunes, 1996); (b) the study of motivational, personality, or cultural factors involved in driving behavior (Carbonell, Montoro, Sanmartín, \& Tortosa, 1995); (c) the analysis of the effects of fatigue and alcohol consumption on driving performance (Buela, Montoro, \& Miró, 1995; Mayor \& Montoro, 1995); and (d) development of practical means and procedures to secure safety conditions in driving (Montoro \& Toledo, 1997).

Lastly, the psychological approach to the study of sport and physical activity is a field of applied research that has been closely connected to basic psychology research. There are at least two broad topics of research that deserve to be mentioned in this review. One is the role of emotional, motivational, and cognitive variables in sport performance at various levels of expertise (Arévalo \& Caracuel, 1995; Cantón \& Mayor, 1994; Mayor \& Cantón, 1996). The other research trend comprises a series of empirical studies intended to measure the patterns of physical activity in sports behavior (Blasco, Capdevila, Pintanel, Valiente, \& Cruz, 1996), and to test the use of biofeedback and other behavioral techniques so as to improve the performance of athletes and sports practitioners (Capdevila, Pintanel, Valiente, \& Cruz, 1995).

\section{Conclusions}

The information that has been reported in the last two sections of this paper is summarized in Figures 1 and 2 . These figures depict the relative weight of the research trends previously examined in terms of the number of researchers (number of faculty) and research teams ascribed to each of them. Figure 1 shows the data for research on basic psychology topics, whereas Figure 2 includes the research trends on other topics (see Tables 2 and 3, for further clarification).

Of all the research trends included in the count of Figure 1 , there are five that correspond to researchers from areas other than basic psychology: two in attention, one in memory, and three in perception. Therefore, the bars showing the number of faculty members participating in the research trends appearing in Figure 1 include researchers from both basic psychology and other areas. If we make a straight 
division of the number of researchers either by research trends or by number of research teams in each field, the mean size of research teams turns out to be rather small (ranging between 2 and 5 researchers per team, with a mean value of 2.9). Moreover, the bars for number of research trends and research teams are virtually identical, except for the case of history of psychology, where the latter is about twice as big as the former. In most cases, particularly those of attention, learning, memory, perception, reasoning, and cognitive impairments, this implies that research teams tend to specialize in a single research trend. In contrast, specialization does not seem to be as dominant in the fields of history of psychology and psycholinguistics, where some research teams regularly address several different issues from a pool of common topics. Once again, as already pointed out in my comments to the data shown in Table 2 (see Section 3), history of psychology emerges as the most

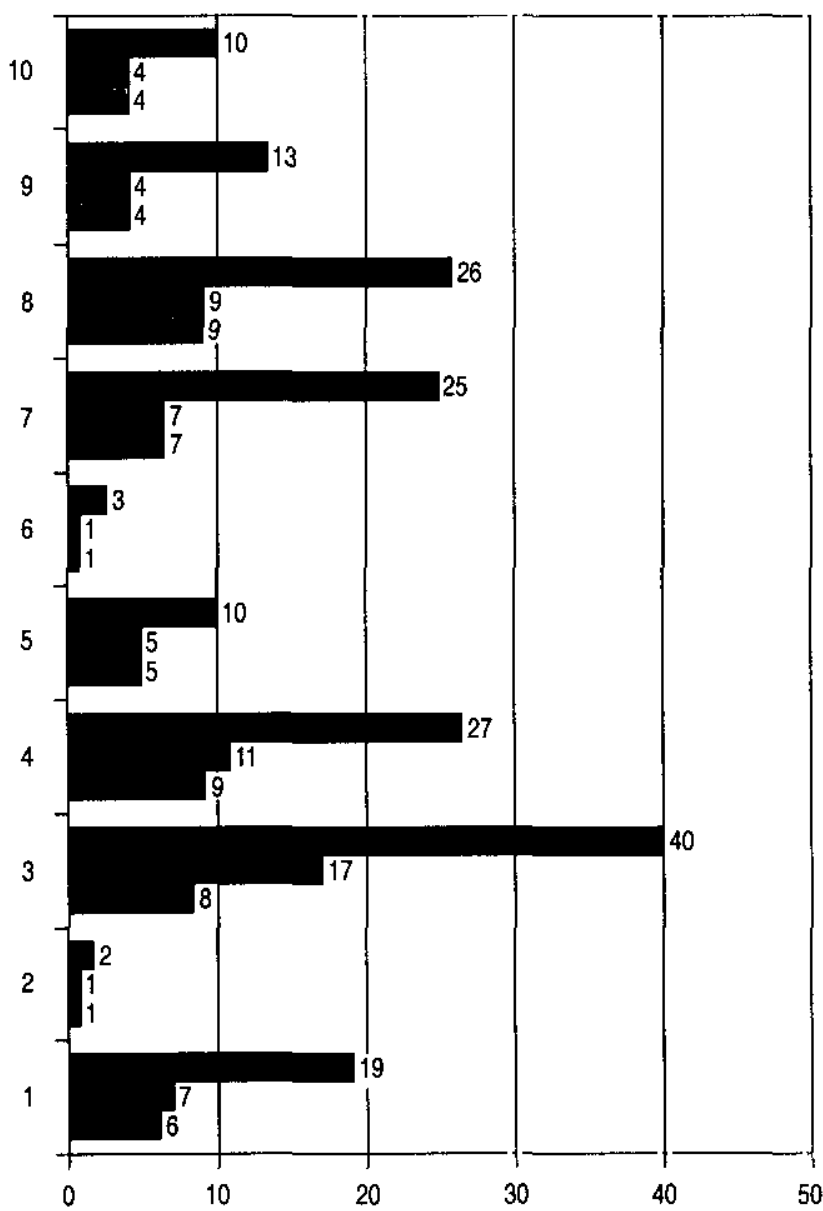

1 Attention; 2 Emotion; 3 History; 4 Learning; 5 Memory; 6 Motivation; 7 Perception; 8 Psycholinguistics, 9 Reasoning; 10 Cognitive impairments.

Figure 1. Main research trends reviewed in this paper within the areas of "Basic Psychology," showing number of different trends, teams and faculty members in each field. developed field of research, especially as far as practising researchers and number of research teams are concerned, followed by psycholinguistics, learning, attention and perception (readers are reminded, however, that the list of researchers on perception includes a fair amount of people from other areas, particularly from methodology).

As for the data shown in Figure 2, there are two points I would like to make: one is the relevance of two highly specific research topics, namely road safety and driving behavior, and sport psychology, both in terms of research teams and number of researchers; the other is the considerable weight of health and clinical psychology research in the area of basic psychology in Spain.

There are two ideas that spring to mind when one tries to draw some general conclusions from the information reported hitherto: One is that research on basic psychology in Spain is extremely heterogeneous and diversified, even

No. of faculty members

No. of research teams

No. of research trends

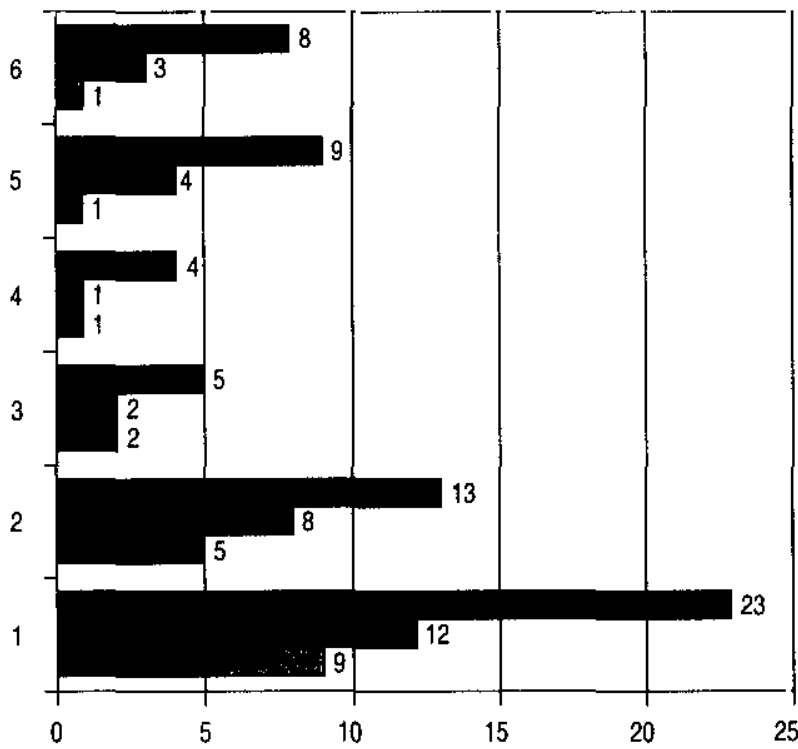

1 Health and Clinical Psychology; 2 Developmental and Educational Psychology; 3 Neuropsychology; 4 Psychology of Gender; 5 Road Safety and Driving Behavior; 6 Sport Psychology.

Figure 2. Main research trends on "Other topics" reported in this paper, showing number of different trends, teams and faculty members in each field. 
more so than is desirabie on some accounts, and the other is that the productivity of Spanish researchers from this area in terms of published materials seems to be rather poor, even by generous standards. However, before endorsing these two rather bleak conclusions, I would like to make some reflections that might help understand and justify these facts.

The diversity of research topics found in Spanish basic psychology can be understood as an immediate consequence of the heterogeneous mixture of subject matters it covers, as an academic unit at the higher education level, and the wide variety of backgrounds exhibited by its faculty members. One fact that might nonetheless seem striking to a foreign observer is the significant bias toward history of psychology, and the substantial amount of research in applied disciplines such as health and educational psychology. On the other hand, in stark contrast to the situation in other Western countries, basic research in cognitive processes is far from being a dominant trend in present-day Spanish psychology. In my view, the reason for this is most likely to be found in the origins and development of psychology as an academic discipline in Spain, and in the division of powers among the dominating elites at the Spanish university during the second half of the twentieth century. In this regard, academic psychology in our country evolved as a branch of the humanities and social sciences, and has remained so for quite a long period. Curiously enough, the gap that separated psychology from the emerging neurosciences in Spain was never closed, and still seems to be wide open. Evidence of this is the blatant disconnection between research in the areas of basic psychology and psychobiology in Spain, with just a few exceptions. Ironically, the first significant influence from abroad came from behaviorism in the early seventies, precisely at a time when the behaviorist paradigm was rapidly fading.

Despite the relatively low impact of our research work at an international scale, research in experimental, cognitive and applied psychology has begun to rise at a steady pace in the last decade. However, researchers in these areas of psychology still have to face a number of hardships. The first important drawback is the short budgets assigned to basic research projects in our country, a consequence being the absolute lack of public research institutions in basic psychology, let alone cognitive science, in Spain. Research is thus entirely left to university departments, whose major source of income is the financial aid that can be gleaned from government funding agencies. A second hindrance is the pervading trend in Spanish universities toward endogamy and lack of mobility of researchers -all the more favored by the administrative autonomy of universities- and the ensuing isolation of research teams or individual researchers. Last, but not least, is the maintenance of an outdated structure of programs and syllabuses in Spanish universities that affects psychology and other related disciplines, and is unfortunately reflected in the organization of research fields. This makes interdisciplinary work a difficult goal to accomplish.

\section{References}

Adarraga, P., \& Zaccagnini, J.L. (1992). DAI: A knowledge-based system for diagnosing autism: A case study on the application of artificial intelligence to psychology. European Joumal of Psychological Assessment, 8, 25-46.

Aguado, L., Brugada, I. de, \& Hall, G. (1997). Effects of a retention interval on the US-preexposure phenomenon in flavor aversion learning. Learning and Motivation, 28, 311-322.

Aguado, L., Hall, G., Harrington, N., \& Symonds, M. (1998). Illness-induced context aversion learning in rats with lesions of the dorsal hippocampus. Behavioral Neuroscience, 112 , 1142-1151.

Aguado, L., Symonds, M., \& Hall, G. (1994). Interval between preexposure and test determines the magnitude of latent inhibition: lmplications for an interference account. Animal Learning and Behavior, 22, 188-194.

Algarabel, S., \& Dasi, C. (1994). Stimulus repetition produces automatic facilitation in a naming task. Perceptual \& Moror Skills, 78,242 .

Algarabel, S., \& Dasi, C. (1997). Efecto de la repetición masiva sobre el tiempo de pronunciación con asincronías estimulares largas y cortas. Cognitiva, 9, 65-82.

Algarabel, S., \& Ruiz, J.C. (1995). Null effect of set size in lexical decision. Perceptual \& Motor Skills, 81, 201-202.

Alonso, C., \& Bayés, R. (1993). Dudas, creencias y opiniones sobre la transmisión del sida en la práctica deportiva. Revista de Psicología del Deporte, 3, 55-66.

Alonso, M.A., \& Fernández, A. (1997). Contexto ambiental y memoria: ausencia de efectos en condiciones de procesamiento optimizado del entorno. Psicológica, 18, 209-225.

Alvarez, R. \& López-Ramírez, M. (1993). Latent inhibition to a compound following exposure to the elements or the compound. Bulletin of the Psychonomic Society, 31, 569-570.

Arce, R, Fariña, F., \& Vila, C. (1996). Perfiles psicosociales como predictores de sesgo en la toma de decisión del jurado. Revista de Psicología Social, 11, 93-102

Arévalo, E., \& Caracuel, J.C., (1995). Estilos atencionales en deportistas universitarios. In J.A. Mora (Ed.), Psicología del deporte en Andalucía (pp. 99-109). Málaga: Edinford.

Arnau, J., Blanca M.J., \& Salvador, F. (1992). Superioridad del procesamiento de los rasgos globales en función de la densidad estimular. Anuario de Psicología, 54,49-60.

Artieta, I., \& Ferrándiz, A. (1991), Estudio bibliométrico del Journal of Experimental Psychology: Learning Memory and Cognition (1980-1989), Revista de Historia de la Psicología, I2, 107-114.

Ávila, C., \& Parcet, M.A. (1997). Impulsivity and anxiety differences in cognitive inhibition. Personality and Individual Differences, 23, 1055-1064

Ballesteros, S., Manga, D., \& Reales, J.M. (1997). Haptic discrimination of bilateral symmetry in 2-dimensional and 3-dimensional unfamiliar displays. Perception and Psychophysics, 59, 37-50

Ballesteros, S., Millar, S., \& Reales, J.M. (1998). Symmetry in haptic and in visual shape perception. Perception and Psychophysics, 60, 389-404 
Bandrés, J., Campos, J.J., \& Llavona, R. (1996). Behavioral observation in America: The Spanish pioneers in the 16th and 17th centuries. Bulletin of the Psychonomic Society, 27, 184187

Bañuls, R., Carbonell, E., \& Miguel-Tobal, J.J. (1993). Inventario de situaciones ansiógenas en el tráfico (ISAT). In M. Forns \& M.T. Anguera (Eds.), Aponaciones recientes a la evaluación psicológica (pp. 209-223). Barcelona: PPU.

Bañuls, R., \& López-Latorre, M.J. (1991). La psicología española a través de la revista Estudios de Psicología: Una aproximación bibliométrica Revista de Historia de la Psicología, 12, 183-194

Barberá, E., \& Albertos, P. (1994). Fuzzy logic modelling of social behaviour. Cybernetics and systems: An international joumal, $25,343-358$.

Barberá, E., \& Cantero, M.J. (1996). Motivación de logro y categorización de género. In I. Garrido (Ed.), Psicología de la motivación (pp. 288-308). Madrid: Síntesis.

Barberá, E, \& Pastor, R. (1992). Género y sexo: transformaciones históricas en el estudio de los roles y los estereotipos. Revista de Historia de la Psicología, 13, 49-58.

Barreto, P., Bayés, R., Comas, M.D., \& Martínez, E. (1996). Assessment of the perception of symptoms and anxiety in terminally ill patients in Spair. Journal of Palliative Care, 12, $43-46$.

Barrio, V. del, Frias, D., \& Mestre, V. (1994). Autoestima y depresión en niños. Revista de Psicología General y Aplicada, 47, $471-476$

Barriopedro, M., \& Botella, J. (1998). New evidence for the zoom model using the RSVP technique. Perception and Psychophysics, 60, 1406-1414.

Bayés, R. (1990). The contribution of behavioural medicine to the research and prevention of AIDS. In D.E. Blackman, \& $\mathrm{H}$. Lejeune (Eds.), Behaviour analysis in theory and practice: Contributions and controversies (pp. 243-258). Hove. UK: Erlbaum.

Bayés, R., Comellas, B., Lorente, S., \& Viladrich, M.C. (1998). Información, miedo y discriminación en la pandemia por VIH/SIDA. Psicothema, 10, 127-134.

Beltrán, F.S., \& Herrando, S. (1995). Measuring the typicality of objects included in environmental scenes: A logistic model for atypicality. Perceptual and Motor Skills, 80, 1343-1352.

Benedet, M.J., \& Caplan, D. (1996). La evaluación neurolinguística de las alteraciones del lenguaje: Presentación de un nuevo instrumento. Revista de Psicología General y Aplicada, 49. 45-63.

Benedet, M.J., Christiansen J.A., \& Goodglass, H. (1998). A crosslinguistic study of grammatical morphology in Spanish- and English-speaking agrammatic patients. Cortex, 34, 309-36.

Bennet, C., Maldonado, A., \& Mackintosh, N. (1995). Learned irrelevance is not the sum of exposure to CS and US. Quartery Journal of Experimental Psychology, 48B, 117-128.

Blanca M.J., Zalabardo C.. Garcia-Criado, F., \& Siles, R. (1994). Hemispheric differences in global and local processing dependent on exposure duration. Neuropsychologia, 32,13431351.
Blanco, A., \& Corte, L. de la (this issue). The decade 1989-1998 in Spanish psychology: An analysis of research on social psychology.

Blanco, M.J., Lamas, J.R., \& Álvarez, A.A. (1992). Esfuerzo y decremento de vigilancia en tareas de discriminación sucesiva y simultánea. Estudios de Psicología, 48, 5-19.

Blasco, T., Capdevila, L., Pintanel, M., Valiente, L., \& Cruz, J. (1996). Evolución de los patrones de actividad física en estudiantes universitarios. Revista de Psicologia del Deporte, 9-10, 51-63.

Blasco, T., \& Inglés, N. (1997). Calidad de vida y adaptación a la enfermedad en pacientes de cáncer durante el tratamiento de quimioterapia, Anuorio de Psicologín, 72, 83-92

Borràs, F.X. (1995). Psiconeuroinmunología: efectos del estrés psicológico sobre la función inmune en sujetos humanos sanos. Ansiedad y Estrés, 1, 19-35.

Borràs, F. X., Estêbanez, E., Gudayol, E., Soriano, C., \& Bayés, R. (1998). Estrés experimental agudo y subpoblaciones de leucocitos en sangre capilar. Ansiedad y Estrés, 4, 59-69.

Bosch, L., \& Sebastián-Gallés, N. (1997). Native-language recognition abilities in 4-month-old infants from monolingual and bilingual environments, Cognition, 65, 33-69.

Bosch, N., \& Serra, M. (1997). Grammatical morphology deficits of Spanish-speaking children with specific language impairment. Amsterdam Series in Child Language Development, 6, 33-46.

Botella, J., García, M.L., \& Barriopedro, M. (1992). Intrusion patterns in rapid serial visual presentation tasks with two response dimensions. Perception and Psychophysics, 52, 547552 .

Bradley, D.C., Sánchez-Casas, R.M., \& García-Albea, J.E. (1993). The status of the syllable in the perception of Spanish and English. Language and Cognitive Processes, 8. 197-233.

Buela, G., Montoro, L., \& Miró, E. (1995). Sueño, fatiga y conducción. In L. Montoro, E. Carbonell, J. Sanmartín, \& F. Tortosa (Eds.), Seguridad vial: del factor humano a las nuevas tecnologias (pp. 203-233). Madrid: Síntesis.

Campos, A. (1995). Imagery, concreteness, emotionality, meaningfulness and pleasantness of words. Perceptual and Motor Skills, 80, 867-880

Campos, A., \& González, M.A. (1994). Influence of creativity on vividness of imagery. Perceptual and Motor Skills, 78, 10671071.

Cana], R., \& Rivière, A. (1993). La conducta comunicativa de los niños autistas en situaciones naturales de interacción. Estudios de Psicologia, 50, 49-74.

Cándido, A., Maldonado, A., \& Vila, J. (1991). Effects of duration of feedback on signaled avoidance. Animal Learning and Behavior, 19, 81-87.

Cantón, E., \& Mayor, L. (1994). The sensation of risk and motivational tendencies on sports: An empirical study. Joumal of Personality and Individual Differences, 16, 777.786.

Cañas, J.J., \& Bajo, M.T. (1994). Strategic associative priming in the lexical decision task. Quarterly Joumal of Experimental Psychology: Human Experimental Psychology, 47A, 383-405. 
Cañas, J.J. ,\& Bajo, M.T. (1996). Automatic and strategic processes in lexical access. In M. Carreiras, J.E. Garcia-Albea, \& N. Sebastián (Eds.), Language processing in Spanish (pp. 61-87). Mahwah, NJ: Erlbaum.

Capdevila, L. Pintanel, M., Valiente, L., \& Cruz, J. (1995). La biorretroalimentación como técnica de entrenamiento psicológico deportivo. Revista de Psicología General y Aplicada,48, 111-123.

Carboneli, E., Bañuls, R., \& Miguel-Tobal, J.J. (1995), El ambiente de tráfico como generador de ansiedad en el conductor. Inventario de situaciones ansiógenas en el tráfico (ISAT). Anuario de Psicologia, 65, 165-183.

Carbonell, E., Montoro, L., Sanmartín, J., \& Tortosa, F. (1995). Percepción por los usuarios de los factores de seguridad y de riesgo en la autopista. Anuario de Psicología, 65, 5982.

Carpintero, H., \& Tortosa, F. (1996). La psicología española a través de la Revista de Psicología General y Aplicada. Revista de Psicología General y Aplicada 49, 373-410.

Carpintero, H., Tortosa, F., \& Peiró, J.M. (1990). Psicólogos europeos en cuatro revistas norteamericanas de psicología. Revista de Historia de la Psicologia, 11, 439-451.

Carrasco, M., Ponte, D., Rechea, C., \& Sampedro, M.J. (1998) "Transient structures": The effects of practice and distractor grouping on within-dimension conjunction searches. Perception and Psychophysics, 60, 1243-1258.

Carreiras, M., \& Clifton, C. (1993). Relative clause interpretation preferences in Spanish and English. Language and Speech, 36, 353-372.

Carreiras, M., Garnham, A., \& Oakhill, J. (1993). The use of superficial and meaning-based representations in interpreting pronouns: Evidence from Spanish. European Journal of Cognitive Psychology, 5, 93-116.

Carreiras, M., Perea, M., \& Grainger, J. (1997). Effects of orthographic neighborhood in visual word recognition; Crosstask comparisons. Journal of Experimental Psychology: Leaming, Memory and Cognition, 23, 857-871.

Carreras, P., \& Fernández-Castro, J. (1998). Evolución de la frecuencia cardiaca de los estudiantes universitarios durante los exámenes. Ansiedad y Estrés, 4, 207-214.

Carretero, M., Asensio, M., \& Pozo, J.I. (1991): Cognitive development, historical time representation and causal explanations in adolescence. In M. Carretero, M.L. Pope, P.R.J. Simons, \& J.I. Pozo (Eds.), Learning and instruction: European research in an intemational context, (Vol. 3, pp. 27-48). Oxford, UK: Pergamon Press.

Carretero, M., López-Manjón, A., \& Jacott, L. (1997). Explaining historical events. Intemational Joumal of Educational Reseanch, 27, 245-253.

Cerezo, M.A., d'Ocón, A., \& Dolz, L. (1996). Mother-child interactive patterns in abusive families versus nonabusive families: An observational study, Child Abuse and Neglect, 20, 573-87.

Choliz, M. (1994). Análisis experimental del efecto placebo. Estudios de Psicologia, 52, 23-35.
Choliz, M. (1995). A breathing-retraining procedure in treatment of sleep-onset insomnia: Theoretical basis and experimental findings. Perceptual and Motor Skills, 80, 507-513.

Costa, A., \& Sebastián-Gallés, N. (1998). Abstract phonological structure in language production: Evidence from Spanish. Journal of Experintental Psychology: Leaming, Memory, and Cognition, 24, 886-903.

Crespo, A., Fernández, J.L., \& Prado, M. del (1994). Efectos de la proximidad del contexto sobre la percepción de triángulos ambiguos. Revista de Psicología General y Aplicada, 47, 397 407.

Cubo, S., Zaccagnini, J.L., \& Adarraga, P. (1995). DID: sistema experto para evaluacion y diagnostico de la depresión. Ciencia Psicológica, 2, 29-52.

Cuetos, F., Valle, F., \& Suárez, M.P. (1996). A case of phonological dyslexia in Spanish. Cognitive Neuropsychology, 13, !-24.

Cuevas, I., \& Ruiz-Vargas, J.M. (1992). The concreteness effect: Dual processing, retrieval demands and bidirectional access. International Journal of Psychology, 27,132.

Davies, G., \& Alonso-Quecuty, M.L. (1997), Cultural factors in the recall of a witnessed event. Memory, 5, 601-614.

Defior, S., Justicia, F., \& Martos, F.J. (1996). The influence of lexical and sublexical variables in normal and poor $S$ panish readers. Reading and Writing, 8, 487-497.

Delgado, A.R., \& Prieto, G. (1996). Sex differences in visuospatial ability: Do performance factors play an important role? Memory and Cognition, 24, 504-510.

Díez, I., Pérez-Delgado, E., \& Mestre, M.V. (1990). La investigación sobre el desarrollo moral a través de Intemational Dissertation Abstracts (1981-1985). Revista de Historia de la Psicología, 11, 423-428.

Dominguez, A., Vega, M. de, \& Cuetos, F. (1997). Lexical inhibition from syllabic units in Spanish visual word recognition. Language and Cognitive Processes, 12, 401-422.

Encinas, M., \& Rosa, A. (1990). El desarrollo institucional de la psicología española de 1900 a 1968. Revista de Historia de la Psicología, 11, 73-121.

Escalona, A., \& Miguel Tobal, J.J. (1995). La ansiedad ante los exámenes: Evolución histórica y aportaciones prácticas para su tratamiento. Ansiedad y Estrés, 2, 195-209.

Escalona, A, \& Miguel Tobal, J.J, (1996). Cognitive-behavioral program to reduce academic test anxiety. Medicine and Mind, $X, 65-88$.

Etxebarría, I., \& Caba, M. A. de la (1998). Consistencia entre cognición y acción moral: conducta solidaria en adolescentes en el contexto escolar. Infancia y Aprendizaje, 81, 83-103.

Ferrándiz, P., \& Pardo, A. (1990). Immunization to learned helplessness in appetitive non-contingent contexts. Animal Learning and Behaviour, 18, 252-256.

Ferrándiz, P., \& Vicente, F. (1997). The conditioned attention theory and bifactorial theory on the learned helplessness syndrome on appetitive contexts. International Journal of Psychology, 32, 399-408.

Fernández, J. (this issue). Research trends in Spanish psychology (1989-1998). 
Fodor, J.A. (1983). The modularity of mind. An essay in faculty psychology. Cambridge, MA: MTT Press

Frías, D., Barrio, V. del, \& Mestre, V. (1991). Children's Depression Inventory (CDI): sus características psicométricas en población extranjera y española. Evaluación Psicológica 7. 377-391.

Fuentes, J.B., \& Robles, S.J. (1992). La naturaleza fenomenológica del conductismo radical de Skinner. Revista de Historia de la Psicología, 10, 61-67.

Fuentes, L.J., \& Ortells, J.J. (1993). Facilitation and interference effects in a Stroop-like task: Evidence in favor of semantic processing of parafoveally-presented stimuli. Acta Psychologica, $84,213-229$.

Fuentes, L.J., \& Tudela. P. (1992). Semantic processing of foveally and parafoveally presented words in a lexical decision task. Quarterly Joumal of Experimental Psychology, 45A, 299-322.

Fuentes, M.J., López, F., Etxebarría, I. Ledesma, A.R., Ontiz, M.J., \& Apocada, P. (1993). Empatía, role-taking y concepto de ser humano, como factores asociados a la conducta prosocial/altruista. Infancia y Aprendizaje, 61, 73-87.

Gallo, M., \& Cándido, A. (1995). Dorsal hippocampal lesions impair blocking but not latent inhibition of taste aversion learning in rats. Behavioral Neuroscience, 109, 1-13.

García, E., Fuentes, J.B., \& Carpintero, H. (1993). Emilio Mira y López y la psicología latinoamericana. Revista de Historia de la Psicología, 14, 3l-55

García-Albea, J.E., Sánchez-Casas, R.M., \& Igoa, J.M. (1998). The contribution of word form and meaning to language processing in Spanish: Some evidence from monolingual and bilingual studies. In D. Hillert (Ed.), Sentence Processing: A cross-linguistic perspective (pp. 183-209). New York: Academic Press.

Garciáa-Pérez, M.A., \& Sierra-Vázquez, V. (1995), Do channels shift their tuning towards lower spatial frequencies in the periphery? Vision Research, 36, 3339-3372.

Gamham, A., Oakhill, J, Ehrlich, M.F., \& Carreiras, M. (1995), Representations and processes in the interpretation of pronouns: New evidence from Spanish and French. Joumal of Memory and Language, 34, 41-62.

Gilboy, E., Sopena, J.M., Clifton, C., \& Frazier, L. (1995). Argument structure and association preferences in Spanish and English complex NPs. Cognition, 54, 131-167.

Girbau, D., \& Boada, H. (1996). Private meaning and comparison process in children's referential communications. Journal of Psycholinguistic Research, 25, 383-396.

Gondra, J.M. (1992). Skinner, la historia y los orígenes de la noción de "operante". Revista de Historia de la Psicologia, 13, 37-43.

González, A. (1997). Metamemoria y aprendizaje de textos. Estudios de Psicología, 58, 59-83.

González, J., Carpintero, H., Peiró, J.M., \& Tortosa, F. (1990). La psicología clínica en España desde los archivos de neurobiología, psicología, fisiología, histología, neurología y psiquiatría (1954-1970). Revista de Historia de la Psicología, 11, 207-219.
González, M.J., \& Arias, F.J. (1995). Perspectiva pragmática del razonamiento: la interpretación del contexto en el condicional. Cognitiva, 7, 93-112.

González-Ordí, H., \& Miguel-Tobal, J.J. (1994). Aplicaciones de las técnicas de hipnosis en el ámbito de la modificación cognitiva-conductual. Informació Psicològica, 53, 41-51.

Grzib, G., Ortega-Mata, R., \& Brengelman, J.C. (1993). Medición de reacciones de estrés en pacientes somáticos y personas sanas. Revista de Psicologia General y Aplicada, 46, 57-69.

Gutiérrez-Calvo, M., \& Cano, A. (1997). The nature of trait anxiety: Cognitive and biological vulnerability. European Psychologist, 2, 301-312.

Gutiérrez-Calvo, M., \& Castillo, M.D. (1995). Plonological coding in reading comprehension: The importance of individual differences. European Joumal of Cognitive Psychology; 7, 365382.

Gutiértez-Calvo, M., \& Castillo, M.D. (1998). Predictive inferences take time to develop. Psychological Research, 61, 249-260.

Gutiérrez-Calvo, M., Szabo, A., \& Capafons, J. (1996). Anxiety and heart rate under psychological stress: The effects of exercise-training. Anxiety, Stress, and Coping, 9, 321-337.

Hernández-Fernaud, E., \& Alonso-Quecuty, M.L. (1997). The cognitive interview and lie detection: A new magnifying glass for Sherlock Holmes? Applied Cognitive Psychology, 11, 55-68.

Herreros de Tejada, P., \& Muñoz Tedó, C. (this issue). The decade 1989-1998 in Spanish psychology: An analysis of research on Psychobiology.

Huertas, J.A., \& Ochaita, E. (1992). The externalization of spatial representation by blind persons. Joumal of Visual Impairment and Blindness, 86, 398-402.

Huertas, J.A, Rosa, A., \& Montero, I. (1991). La Troika: un análisis del desarrollo de las contribuciones de la Escuela SocioHistórica de Moscú. Anuario de Psicología, 4, 113-128.

lgoa, J.M., Carreiras, M., \& Meseguer, E. (1998). A study on late closure in Spanish: Principle-grounded vs. frequency-based accounts of attachment preferences. Quarterly Journal of Experimental Psychology: Human Experimental Psychology, 51A, 561-592.

Jiménez, L., Méndez, C., \& Cleeremans, A. (1996). Comparing direct and indirect measures of sequence learning Journal of Experimental Psychology: Learning, Memory and Cognition, 22, 948-969.

Lafuente, E., \& Ferrándiz, A. (1991). Estado actual de la historiografía de la psicología en España. Un análisis de la Revista de Historia de la Psicología (1980-1987). Revista de Historia de la Psicología, 12, 37-46.

Lafuente, E., \& Ferrándiz, A. (1992). Psicología de la Gestalt en España (1920-1989). Un estudio a través de las publicaciones periódicas especializadas. Revista de Historia de la Psicologia, $10,109-116$

Lafuente, J., \& Barberá, E. (1995). Desarrollo de la persona sexuada aduita. Revista de Psicología de la Educación, 17, 65-93.

Lamas, E., \& Pellón, R. (1997). Food deprivation and food-delay effects on the development of adjunctive drinking. Physiology and Behavior, 61, 153-158. 
León, J.A. (1997), The effecrs of headlines and summaries on news comprehension and recall. Reading \& Writing, 9, 85-106.

León, J.A., \& Carretero, M. (1992). Signal effects on the recall and understanding of expository texts in expert and novice readers. In A. Oliveira (Ed.), Hypermedia courseware: Structures of communication and intelligent help (pp. 97-111). Nueva York: Springer Veriag.

León-Carrión. J. (1997a). Rehabilitation of memory. In J. LeónCarrión (Ed.), Neuropsychological rehabilitation: Fundamentals, innovations and directions (pp. 371-398). Delray Beach, FL: St. Lucie Press.

León-Carrión, J. (1997b). An approach to the treatment of affective disorders and suicide tendencies after TBI. In J. León-Carrión (Ed.), Neuropsychological rehabilitation: Fundamentals, innovations and directions (pp. 415-429). Delray Beach, FL: St. Lucie Press.

Lillo, J. (1995). Flujo óptico y conducción: características generales y velocidad percibida. Anuario de Psicologia, 65, 101-114.

Lillo, J., Sánchez, P., Collado, J., Ponte, E., \& Garcia, C. (1998). TIDA: A children's test to assess dysfunctions in the perception of colour. Psychology in Spain, 1, 48-56.

López, F., Shanks, D., Almaraz, J., \& Fernández Berrocal, P. (1998). Effects of trial order on contingency judgments: A comparison of associative and probabilistic contrast accounts. Journal of Experimental Psychology: Leaming, Memory and Cognition, $24,672-694$

López-Ramirez, M., \& Aguado, L. (1992). Effects of element or compound preexposure on taste-aversion learning with simultaneous and serial compounds. Bulletin of the Psychonomic Society, 30, 279-282.

López-Manjón, A., \& Carretero, M. (1993). Teorias intuitivas sobre la enfermedad y razonamiento correlacional en expertos y profanos. Cognitiva, 5. 95-111.

López-Ornat, S. (1997). What lies in between a pre-grammatical and a grammatical representation? In W.R. Glass \& A-T.PérezLeroux (Eds.), Contemporary perspectives on the acquisition of Spanish (pp. 3-20). Somerville, MA: Cascadilla Press.

Loy, I., Alvarez, R., Rey, V., \& López-Ramírez, M. (1993). ContextUS associations rather than occasion setting in taste aversion learning. Learning and Motivation, 24, 55-72.

Luna, D., \& Merino, J.M. (1998). Primacía del procesamiento de la información global y local en percepción visual. Revista de Psicología General y Aplicada, 51, 373-384.

Machuca, F., Carrasco, J.M., González, A., \& León-Carrión, J. (1997). Training for social skills after brain injucy. In J. LeónCarrión (Ed.), Neuropsychological rehabilitation: Fundamentals, innovations and directions (pp. 453-468). Delray Beach, FL: St. Lucie Press.

Manzanero, A., \& Diges, M. (1994). El papel de la preparación sobre el recuerdo de sucesos imaginados y percibidos. Cognitiva, 6, 27-45.

March, J., Diez-Chamizo, V., \& Mackintosh, N.J. (1992). Reciprocal overshadowing between intra-maze and extra-maze cues. Quarterly Journal of Experimental Psychology, 45B, 49. 63.
Marcos, J.L. (1998). Effects of aversive classical conditioning on habituation of unconditioned skin conductance responses. Psicothema, 10, 175-181.

Martí, C., Tortosa, F., \& Carpintero, H. (1992). José Germain, neuropsiquiatra español, Revista de Historia de la Psicología, 10. 117-128.

Martínez, M.., Forns, M.., \& Boada, H. (1997). Estudio longitudinal de la comunicación referencial en niños de 4 a 8 años. Anuario de Psicologia, 75, 37-58.

Martínez-Sánchez, F., Ortiz, B., \& Fernández-Castro, J. (1998). El índice de sudoración palmar: un procedimiento de evaluación de la reactividad autónoma en el estudio del estrés inducido experimentalmente. Ansiedad y Estrés, 4, 227-238.

Martos, FJ. (1995). Speed of visual information processing in developmental dyslexia: Speed of processing in dyslexic children. In C.K. Leong \& J.R. Malatesha (Eds.), Developmental and acquired dyslexia: Neuropsychological and neurolinguistic perspectives. Neuropsychology and cognition (Vol. 9, pp. 51-59). Dordrecht, Netherlands: Kluwer

Martos, R., Catena, A., Maldonado, A., \& Ramírez, E. (1995). Respuestas de predicción y juicios de contingencia: el papel de la capacidad predictiva y la predictibilidad. Psicológica, 15, 411-427.

Mateos, M. (1995). Programas de intervención metacognitiva dirigidos a la mejora de la comprensión lectora. Características y efectividad. In M. Carretero, J. Almaraz, \& P. Fernández Berrocal (Eds,), Razonamiento y comprensión (pp. 327-345). Madrid: Trotta, 1995.

Mayor, J. (1993). Bases psicológicas para el trabajo social en drogodependencias. In C. Navalón \& M.E. Medina (Eds.), Psicologia y Trabajo Social (pp. 473-493). Barcelona: DM \& PPU.

Mayor, J., \& González-Marqués, J. (1994). Facilitation and interference effects in word and picture processing. In $S$. Ballesteros (Ed.), Cognitive approaches to human perception (pp. 155-198). Hilisdale, NJ: Erlbaum.

Mayor, L., Cano, L., Cantón, E., \& Sos-Peña, M.R. (1992). The motivational analysis in the addiction process. In M. Sabourin (Ed.), Intemational Joumal of Psychology (p. 643). Hove, UK: Eribaum.

Mayor, L., \& Cantón, E. (1996). Aspectos cognitivo-motivacionales de la práctica física y deportiva. In I. Garrido (Ed.), Psicología de la motivación (pp. 259-286). Madrid: Síntesis.

Mayor, L., \& Montoro, L. (1995). Las drogas de abuso y sus efectos en la seguridad vial. In L. Montoro, E. Carbonell, J. Sanmarín, \& F. Tortosa (Eds.), Seguridad vial: del factor humano a las nuevas tecnologias (pp. 257-269). Madrid: Síntesis.

Méndez, C., \& Jiménez, L. (1998). Adquisición automática e implicita: precisiones acerca del papel de la atención. Cognitiva, 10, 131-135.

Merino, J.M., \& Luna, D. (1997), Procesos sensoriales y primacía de la información global y local. Cognitiva, 9, 159-00.

Mestre, M.V., Martí, M., \& Samper, P. (1996). Productividad científica en psicología y la variable género: un estudio a través de la Revista de Psicología General y Aplicada. Revista de Historia de la Psicología, I7, 121-133. 
Mestre, M.V., \& Pérez Delgado, E. (1997). Cognición y afecto en el desarrollo moral. Evaluación y programas de intervención. Valencia: Promolibro.

Miera, G., \& Cuetos, F. (1998). Understanding disorders in agrammatic patients: Capacity or structural deficits? Brain and Lattuage, 64, 328-338.

Mitchell, D.C., Cuetos, F., Corley, M.M.B., \& Brysbaert, M. (1995). Exposure-based models of human parsing: Evidence for the use of coarse-grained (nonlexical) statistical records. Joumal of Psycholinguistic Research, 24, 469-488

Moix, J. (1996). ¿Puede el paciente bajo anestesia general procesar información? Medicina Clinica de Barcelona, 107, 416-417.

Moix, J. (1997). Evaluación de la ansiedad en la antesala del quirófano. Medicina Clínica de Barcelona, 108, 157-158.

Moix, J., Bassets, J., \& Caselles, R.M. (1998). Efectividad de un audiovisual como preparación para la cirugía en pacientes pediátricos. Cirugía Pediátrica, $11,25-29$.

Montoro, L., \& Toledo, F. (1997). El accidente: prevención y estrategias de intervención. In L. Montoro \& F. Toledo (Eds.), El factor humano en la conducción de trenes: manual de conducción segura (pp. 31-53). Valencia: INTRAS.

Morales, A., Torres, M.D., Megías, J.L., \& Cándido, A. (1992). Effect of diazepam on successive negative contrast in one-way avoidance learning. Phamacology, Biochemistry and Behavior. $43,153-157$.

Ochaita, E., \& Rosa, A. (1990). Percepción, acciốn y conocimiento en los niños ciegos. In A. Marchesi, C. Coll, \& J. Palacios (Eds.), Desarrollo psicológico y educación: III. Necesidades educativas especiales y aprendizaje escolar (pp. 211-227). Madrid: Alianza.

Olivar, S., \& Belinchon, M. (1997). Ineficacia en la comunicación referencial de personas con autismo y otros trastornos relacionados: un estudio empírico. Anuario de Psicologia, 75, 119-145.

Ortells, J.J., \& Tudela, P. (1996). Positive and negative semantic priming of attended and unattended parafoveal words in a lexical decision task. Acta Psychologica. 94, 209-226.

Ortells, J.J., Tudela, P., Noguera, C., \& Abad, M.J.F. (1998). Attentional orienting within visual field in a lexical decision task. Joumal of Experimental Psychology: Human Perception and Performance, 24, 1675-1689.

Pallier, C., Sebastián-Gallés, N., Oupoux, E., \& Mehler, J. (1998). Perceptual adjustment to time-compressed speech: A crosslinguistic study. Memory and Cognition, 26, 844-851.

Pallier, C., Sebastián-Gallés, N., Felguera, T., \& Christophe, A. (1993). Attentional allocation within the syllabic structure of spoken words. Journal of Memory and Language, 32, 373389.

Palmero, F., \& Choliz, M. (1991). Resting heart rate (HR) in women with and without premenstrual symptoms (PMS), Journal of Behavioral Medicine, 14, 125-139.

Palmero, F., Codina, V., \& Rosel, J. (1993). Psychophysiological activation, reactivity, and recovery in Type $A$ and Type $B$ scorers when in a stressful laboratory situation. Psychological Reports, 73, 803-811.
Pedraja, M.J., Vera, J.A., \& Quiñones E. (1996). Una aproximación a la historia de la psicologia a través del Journal of the History of Behavioral Sciences. Revista de Historia de la Psicologia, 17, 325-335.

Pelión, R., \& Blackman, D.E. (1992). Effects of drugs on the temporal distribution of schedule-induced polydipsia in rats. Phamacolagy Biochemistry and Behavior, 43, 689-695.

Peraita, H., \& Malrieu, D. (1998). La relevancia de las partes en el sistema léxico-conceptual humano. Estudios de Psicología, $60,111-128$.

Perea, M., \& Gotor, A. (1996). Effects of masked repetition priming and orthographic neighborhood in visulal recognition of words. Perceptual and Motor Skills, 83, 179-186.

Perea, M., \& Gotor, A. (1997). Efectos de la repelición enmascarada de la palabra en la decisión léxica: el papel de la frecuencia y la vecindad, Revista de Psicología General y Aplicada, 50, 185-197.

Pérez-Delgado, E. (1994). La capacidad de razonamiento moral en jovenes adolescentes. Revista de Edacación, 303, 261-280.

Pérez-Dejgado, E., \& Mestre, M. V. (1993). Visibilidad de una obra clásica en psicología moral a través de mantales introductorios de psicología evolutiva: "Studies in the Nature of Character" (1928-1930) de H. Hartshorne y M. May. Revista de Historia de la Psicologia, 14, 13-29.

Pérez-Delgado, E., Mestre, M.V., \& García-Ros, R. (1990). Los autores que citan a Freud en ciencias sociales. Revista de Historia de la Psicología. 11, 297-304.

Pérez-Delgado, E., \& Oliver, J.C. (1995). The influence of age and formal education on moral reasoning in a sample from Spain. Journal of Moral Education, 24, 65-72.

Pérez-Garrido, A., Tortosa, F., \& Calatayud, C. (1997). De un puesto en la investjgación a otro en la historia. El uso de J.B.Watson en las revistas de psicología durante los últimos 80 años. Revista de Historia de la Psicologia, 18, 289-300.

Phillips, W., Gornez, J.C., Baron-Cohen, S., Laa, V., \& Riviére, A. (1995). Treating people as objects, agents, or "subjects": How young children with and without autism make requests. Joumal of Child Psychology and Psychiatry, 36, 1383-1398.

Pitarque, A., Algarabel, S., \& Meseguer, E. (1992). Degree of elaborative processing in two implicit and two explicit memory tasks. Bulletin of the Psychonomic Society, 30, 217-220.

Pitarque, A., Ruiz, J.C., \& Algarabel, S. (1995). Simulation of dissociative effects on explicit implicit memory tasks from a connectionist model. Psicothema, 7, 339-350.

Postigo, Y., \& Pozo, J.I. (1998). The learning of a geographical map by experts and novices. Educational Psychology, 18, 6580 .

Pozo, J.I., \& Carretero, M. (1991). Causal theories, reasoning strategies and cognitive conflicts in Newtonian mechanics. In A. Demetriou, M. Shayer, \& A. Efklides (Eds.), Neo-piagetian theories of cognitive development (pp. 231-255). London: Routledge.

Prieto, G., Carro, J., Pulido, R.F, Orgaz, B., Delgado, A.R., \& Loro, P. (1996). Medición de la visualización espacial mediante tests informatizados. Estudios de Psicologia, 55, 41-59. 
Prieto, J.M., Fernández-Ballesteros, R., \& Carpintero, H. (1994). Contemporary psychology in Spain. Annual Review of Psychology, 45, 51-78.

Quintana, J. (1990). Wundt, Maudsley, Brentano. Cara y cruz del metodo introspectivo, Revista de Historia de la Psicología, 11, 273-288.

Ramírez, J.D. (1994). Adule learning literacy. The role of private speech in reading comprehension, In V. John-Steiner, C. Panofsky, \& L. Smith (Eds.), Interactionist approach to language and literacy (pp. 305-330). Cambridge, MA: Cambridge University Press.

Recarte, M.A., \& Nunes, L.M. (1996). Perception of speed in an automobile: Estimation and production. Joumal of Experimental Psychology: Applied, 2, 291-304.

Recarte, M.A., Nunes, L.M., López, R., \& Recarte, S. (1998). Recursos atencionales y parámetros oculares en la conducción. In J. Botella \& V. Ponsoda (Eds.), La arención: un enfoque pluridisciplinar (pp. 373-385). Valencia: Promolibro.

Rodrigo, T., Diez-Chamizo, V., McLaren, I.P.L.. \& Mackintosh, N.J. (1994). Effects of the pre-exposure to the same or different pattern of extra-maze cues on subsequent extra-maze discrimination. Quanterly Journal of Experimental Psychology, 47B, 15-26.

Rodríguez-Saavedra, R., \& Cano, A. (1995). Relación entre adquisición y patrón de respuestas de ansiedad en la fobia dental. Ansiedad y Estrés, 1, 105-111.

Rosa, A. (1993). La polisemia de la palabra "historia": historiapasado, historiografia, historia-narración e historia intelectual. Revista de Historia de la Psicología, 14, 1-7.

Rosa, A. (1994). What do people consume history for? (If they do). Learning history as a process of knowledge consumption and constnuction of meaning. In M. Carretero \& J. Voss (Eds.), Learning processes in history and social sciences (pp. 221233). Hillsdale, NJ: Erlbaum.

Rosa, A., Huertas, J.A., Blanco, F., \& Montero, I. (1993). What is the place of History of Psychology? Some thoughts about methodology. Revista de Historia de la Psicologia, Monographs 2, 271-223.

Rosas, J.M., \& Alonso, G. (1997). Forgetting of the CS duration in rats: The role of retention interval and training level. Learning-and-Motivation, 28, 404-423.

Rosselló, J., Munar, E., Arias, R., \& Justo, S. ( 1996 ). Impairment in shifting and dividing attention al low blood alcohol levels. International Journal of Psychology, 31, 19.

Rosselló, J., Munar, E., Justo, S., \& Arias, R. (1998). Efectos del alcohol sobre la atención dividida y la precisión del cambio atencional. Psicothema, 10, 65-73.

Ruiz, G., Sánchez, N., \& Casa, L.G., de la (1998). Reflexiones de unos psicólogos experimentales con aficiones históricas. Anuario de Psicología, 29, 62-65.

Ruiz-Vargas, J.M., Cuevas, I., \& Marschark, M. (1996). The effects of concreteness on memory: Dual codes or dual processing? The European Journal of Cognitive Psychology, 8, 45-72.

Ruiz-Vargas, J.M., Cuevas, I., \& López-Frutos, J.M. (1998). El proceso de control de la realidad en sujetos con propensión a la alucinación. Psicothema, 10,41-52.
Saiz, M., \& Saiz, D. (1994). Análisis bibliométrico de la revista Anuario de Psicología. Una aproximación a un cuarto de siglo de psicología en la Universidad de Barcelona. Anuario de Psicología, 63, 25-46.

Saiz, M., Saiz, D., Mülberger, A., \& Gabucio, F. (1991). Una aproximación a la escuela de la Gestalt a través del análisis de la revista Psychologische Forschung (1922-1938). Revista de Historia de la Psicología, 12, 77-87.

Salavert, F., Pelegrina, M., \& Beltrán, F.S. (1998). Figure-ground perceptual organization and learning by three-year-olds. Perceptual and Motor Skills, 86, 488-490.

Sánchez, J.C., \& Fernández. T.R. (1990). Reconsideración histónica de la selección natural. Revisfa de Historia de la Psicología, 11, 517-528.

Sánchez-Hernández, A., Pedraja, M.J., Quiñones, E.. \& Martínez, F. (1996). A historic-quantitative approach to psychophysiological research: The first three decades of the journal Psychophysiology (1964-1993). Psychophysiology, 33, 629-636.

Sánchez-Miguel, E. \& García-Sánchez, J. N. (this issue). The decade 1989-1998 in Spanish psychology: An analysis of research in Developmental and Educational Psychology.

Sanz, A., Pozo, J.I., Pérez, M.P., \& Gómez-Crespo, M.A. (1996). El razonamiento proporcional en expertos y novatos: el efecto del contenido. Revista de Psicología General y Aplicada. 49, $337-352$.

Sanz, J. (this issue). The decade 1989-1998 in Spanish psychology: An analysis of research in Personality, Assessment, and Psychological Treatment (Clinical and Health Psychology).

Sarriá, E, \& Rivière, A. (1991). Desarrollo cognitivo y comunicación intencional preverbal: un estudio longitudina] multivariado. Estudios de Psicologia, 46, 35-52.

Sebastián-Gallés, N. (1991). Reading by analogy in a shallow orthography. Journal of Experimental Psychology: Human Perception and Performance, 17, 471-477.

Sebastián-Gallés, N., Dupoux, E., Seguí, J., \& Mehler, J. (1992). Contrasting syllabic effects in Catalan and Spanish. Joumal of Memory and Language, 31, 18-32.

Sierra-Vázquez, V., \& García-Pérez, M.A. (1995). Psychophysical I-D wavelet analysis and the appearance of visual contrast illusions. IEEE Transactions: Systems, Man, \& Cybernetics, 25, 1424-1433.

Sotillo, M., \& Rivière, A. (1997). Algunas cuestiones sobre el desarrollo del lenguaje de referencia mental: los problemas de los niños con el lenguaje de estados mentales. Estudios de Psicología, 57, 39-59.

Torres, M.C., Morales, A, Cándido, A., \& Maldonado, A. (1996). Successive negative contrast in one-way avoidance: Effects of thiopental sodium and chlorpromazine. The European Joumal of Phamacology, 314, 260-275.

Tortosa, F., Calatayud, C., \& Pérez-Garrido, A. (1992). E,G.Boring en la historiografía psicológica contemporánea. Revista de Historia de la Psicologia, 13, 335- 352.

Tortosa, F., Calatayud, C., \& Pérez-Garrido, A. (1996). ¿Hechos o ficciones para una identidad disciplinar? J.B.Watson en los manuales. Revista de Historia de la Psicología, 17, 235-246. 
Valiña, M.D., Seoane, G., Feraces, M.J., \& Martín, M. (1998). La tarea de selección de Wason: ¿efecto de contenido, efecto de las instrucciones o ambos? Estudios de Psicologia., 60, 15-34.

Valle, F. (1996). Dual-route models in Spanish: Developmental and neuropsychological data. In M. Carreiras, J.E. GarcíaAlbea, \& N. Sebastián-Gallés (Eds.), Language processing in Spanish (pp. 89-118). Mahwah, NJ: Erlbaum.

Vega, M. de (1995). Backward updating of mental models during continuous reading of narratives. Journal of Experimental Psychology: Learning, Memory and Cognition, 21, 373-386.

Vega, M. de, Díaz, J.M., \& León, I, (1997). To know or not to know. Comprehending protagonist's beliefs and their emotional consequences. Discourse Processes, 23, 169-192.
Vera, J.A., Quiñones, E., Sánchez, A., \& Pedraja, M.J. (1991). La visibilidad de autores hispanoparlantes y lusoparlantes a través de la Revista Latinoamericana de Psicología (1979-1988). Revista de Historia de la Psicología, 12, 307-318.

Vigil, A., Ferrando, P.J., \& Pueyo, A.A. (1993). Initial stages of information processing and inspection time: Electrophysiological correlates, Personality and Individual Differences, 14, 733-738.

Viso, S. del, Igoa, J.M., \& García-Albea, J.E. (1991). On the autonomy of phonological encoding: Evidence from slips of the tongue in Spanish. Journal of Psycholinguistic Research, $20,161-185$.

Zalbidea, A., Tortosa, F., \& Carpintero, H. (1989). La imagen de Abraham Maslow a travếs de la opinión personal de algunos de sus máximos citadores. Revista de Historia de la Psicología, $10,423-430$. 